\title{
Role of Epidural Steroids in the Management of Chronic Spinal Pain: A Systematic Review of Effectiveness and Complications
}

\author{
Salahadin Abdi, MD, PhD, Sukdeb Datta, MD, and Linda F. Lucas, MD
}

Background: Epidural steroid injections are commonly used for chronic spinal pain. However, there is no conclusive evidence regarding their effectiveness, and debate continues as to their value in managing chronic spinal pain.

Objective: To evaluate various types of epidural injections (interlaminar, transforaminal, and caudal) for managing chronic spinal pain (axial and radicular).

Study Design: A systematic review utilizing the criteria established by the Agency for Healthcare Research and Quality (AHRQ) for evaluation of randomized and non-randomized trials, and criteria of the Cochrane Musculoskeletal Review Group for randomized trials.

Methods: Data sources included relevant English literature identified through searches of MEDLINE and EMBASE (January 1966 to November 2004), manual searches of bibliographies of known primary and review articles and abstracts from scientific meetings within the last 2 years.

Three reviewers independently as- sessed the trials for the quality of their methods. Subgroup analyses were performed for trials with different control groups, with different modes of epidurals (interlaminar, transforaminal, and caudal), with different injection sites (cervical/thoracic, lumbar/ sacral), and with timing of outcome measurement (short- and long-term).

Outcome Measures: The primary outcome measure was pain relief. Other outcome measures were functional improvement, improvement of psychological status, and return to work. Short-term improvement was defined as less than 6 weeks, and longterm improvement was defined as 6 weeks or longer.

Results: For lumbar radicular pain with interlaminar lumbar epidural steroid injections, the level of evidence was strong for short-term relief and limited for long-term relief. For cervical radicular pain with cervical interlaminar epidural steroid injections, the evidence was moderate.

The evidence for lumbar transforaminal epidural steroid injections for lumbar nerve

root pain was strong for short-term and moderate for long term improvement. The evidence for cervical transforaminal epidural steroid injections for cervical nerve root pain was moderate. The evidence was limited for lumbar radicular pain in post lumbar laminectomy syndrome.

The evidence for caudal epidural steroid injections was strong for short-term relief and moderate for long-term relief. For managing chronic postlumbar laminectomy syndrome and spinal stenosis the evidence was limited for low back and radicular pain. The evidence was moderate for chronic low back pain.

Conclusion: The evidence for effectiveness of epidural injections in managing chronic spinal pain ranged from limited to strong.

Keywords: Spinal pain, low back pain, epidural steroids, interlaminar, caudal, transforaminal, radiculopathy, axial pain, spinal stenosis

impact on general health (4-18) showed significant disability in all ages of the population with the elderly suffering not only with pain of longer duration, but with a higher frequency; musculoskeletal symptoms for multiple body parts ( 2 or more) were more prevalent ( $64 \%$ of all workers) than those for single body regions (19\%); and chronic persistent back pain and neck pain in children and adults is seen in up to $60 \%$ of patients, as long as 5 years or longer after the initial episode.

Epidural injections with or without corticosteroids is one of the commonly used interventions in managing chronic spinal pain $(1,19)$. However, the use of epidural steroid injections is still debated. Several approaches are available to access the lumbar epidural space: interlaminar, transforaminal, and caudal ( 1 , 20-23). There are substantial differences between the three approaches. The interlaminar entry is directed more closely to the assumed site of pathology requiring less volume than the caudal route. The transforaminal approach is target specific using the smallest volume in fulfilling the aim of reaching the primary site of pathology; namely the ventrolateral space. In contrast, the caudal entry is relatively easily achieved with minimal risk of inadvertent dural puncture, but requiring high volumes of injectate to reach target structures. Due to inherent variations, differences, advantages, and disadvantages applicable to each technique (including effectiveness and outcomes), interlaminar epidural injections (cervical, thoracic and lumbar epidural injections) transforaminal epidural injections (cervical, thoracic and lumbosacral), and caudal epidural injections are considered as separate entities 
Table 1. Designation of levels of evidence

\begin{tabular}{|c|}
\hline $\begin{array}{l}\text { Level I - Conclusive } \\
\text { Research-based evidence with multiple relevant and high-quality scientific studies or } \\
\text { consistent reviews of meta-analyses }\end{array}$ \\
\hline $\begin{array}{l}\text { Level II - Strong } \\
\text { Research-based evidence from at least one properly designed randomized, controlled trial; } \\
\text { or research-based evidence from multiple properly designed studies of smaller size; or } \\
\text { multiple low quality trials. }\end{array}$ \\
\hline $\begin{array}{l}\text { Level III - Moderate } \\
\text { a) Evidence obtained from well-designed pseudorandomized controlled trials (alternate } \\
\text { allocation or some other method); b) evidence obtained from comparative studies with } \\
\text { concurrent controls and allocation not randomized (cohort studies, case-controlled studies, } \\
\text { or interrupted time series with a control group); c) evidence obtained from comparative } \\
\text { studies with historical control, two or more single-arm studies, or interrupted time series } \\
\text { without a parallel control group. }\end{array}$ \\
\hline $\begin{array}{l}\text { Level IV - Limited } \\
\text { Evidence from well-designed nonexperimental studies from more than one center or } \\
\text { research group; or conflicting evidence with inconsistent findings in multiple trials }\end{array}$ \\
\hline $\begin{array}{l}\text { Level V - Indeterminate } \\
\text { Opinions of respected authorities, based on clinical evidence, descriptive studies, or reports } \\
\text { of expert committees. }\end{array}$ \\
\hline
\end{tabular}

Adapted from ref 1

within epidural injections. As such, they should be discussed individually.

The mechanism of action of epidural injections is not well understood. It is believed that neural blockade alters or interrupts nociceptive input, reflex mechanisms of the afferent limb, self-sustaining activity of the neuron pools and neuraxis, and the pattern of central neuronal activities. Explanations for improvements are based in part on the pharmacological and physical actions of local anesthetics, corticosteroids, and other agents. It is believed that local anesthetics interrupt the painspasm cycle and reverberating nociceptor transmission, whereas corticosteroids reduce inflammation either by inhibiting the synthesis or release of a number of pro-inflammatory substances and by causing a reversible local anesthetic effect (24-37), even though an inflammatory basis for either axial or radicular pain has not been proven $(32,38,39)$.

This systematic review was undertaken due to conflicting opinions and inconclusive evidence in the literature ( 1 , $20,23,40-47)$. Further, authors of this review strongly believe that due to the inherent variations and differences in the 3 techniques applied in the delivery of epidural steroids, most of the previous reviews were not only incomplete, but also inaccurate. Thus, due to variations, differences, advantages, and disadvantages applicable to each technique, interlaminar epidural injections, transforaminal epidural injections, and caudal epidural injections are considered as separate entities.

\section{Methods}

\section{Literature Search}

Our literature search included MEDLINE and EMBASE (Jan 1966 - Nov 2004), systematic reviews, narrative reviews, cross-references to the reviews and various published trials; and peer reviewed abstracts from scientific meetin the English language. The search strategy consisted of diagnostic interventional techniques, epidural injections and steroids, interlaminar epidurals, transforaminal epidurals, nerve root blocks, and caudal epidural steroids, with emphasis on chronic pain/low back pain/neck pain/ mid back or thoracic pain or spinal pain.

\section{Selection Criteria}

The review focused on randomized and non-randomized evaluations, and reports of complications. The population of interest was patients suffering with chronic spinal pain for at least 3 months. Three ings during the past two years, published types of epidural injections with local anesthetic, steroid, or other drugs, provided for management of spinal pain were evaluated. All the studies providing appropriate management with outcome evaluations of 3 months and statistical evaluations were reviewed. The primary outcome measure was pain relief at various points. The secondary outcome measures were functional or psychological improvement, return to work, and complications.

For evaluating the quality of individual articles, we have used the criteria from the Agency for Healthcare Research and Quality (AHRQ) publication (48), as shown in Appendix A to D. For evaluation of randomized trials, criteria described by Cochrane Review Group for musculoskeletal disorders (49) also have been utilized (Appendix E).

For studies to be included, an algorithmic criteria should have been met (Appendix F) and a study should answer positive questions (at least partially) in all three categories $(1,50)$.

\section{Data Extraction}

Study evaluation and inclusion and exclusion is shown in Appendix F. Methodologic quality assessment was performed as described in the Appendices.

\section{Analysis of Evidence}

Qualitative analysis was conducted, using five levels of evidence for effectiveness of epidural steroids as illustrated in Table 1. Pain relief was evaluated on both a short-term (less than 6 weeks) and longterm (6 weeks or longer) basis. A study was judged to be positive if the authors concluded that the epidural steroid injection therapy was more effective than the reference treatment in randomized trials, or concluded that it was effective in observational studies. All other conclusions were considered negative. If, in the opinion of the reviewers, there was conflict with the conclusion, appropriate explanations were provided.

\section{RESULTS}

\section{Interlaminar Epidural Injections}

Our search strategy yielded a total of 236 articles. Relevant studies evaluating the effectiveness of interlaminar epidural injections, specifically lumbar epidural injections included 19 randomized or double blind trials (51-69), 8 non-randomized prospective trials (68-77), and multi- 
Table 2. Characteristics of published randomized trials of lumbar interlaminar epidural injections

\begin{tabular}{|c|c|c|c|c|c|}
\hline Study/Methods & Participants & Intervention(s) & Outcome(s) & Result(s) & Conclusion(s) \\
\hline & & & & \multicolumn{2}{|c|}{$\begin{array}{l}\text { Short-term relief }<6 \text { wks; } \\
\text { Long-term relief } \geq 6 \text { wks }\end{array}$} \\
\hline $\begin{array}{l}\text { Carette et al (65) } \\
\text { Randomized double } \\
\text { blind trial } \\
\text { AHRQ Score } \\
10 / 10 \\
\text { Cochrane Score } \\
10 / 10\end{array}$ & $\begin{array}{l}158 \text { patients with sciatica } \\
\text { due to a herniated nucleus } \\
\text { pulposus. } \\
\text { Treatment group: } 78 \\
\text { Placebo group: } 80\end{array}$ & $\begin{array}{l}\text { Experimental group: } \\
\text { methylprednisolone } \\
\text { acetate ( } 80 \mathrm{mg} \text { and } 8 \\
\text { mL of isotonic saline) } \\
\text { Control group: iso- } \\
\text { tonic saline } 1 \mathrm{~mL} \\
\text { Frequency: } 3 \text { epidural } \\
\text { injections } 3 \text { weeks } \\
\text { apart. }\end{array}$ & $\begin{array}{l}\text { Timing: } 6 \text { weeks, } 3 \\
\text { months, } 12 \text { months } \\
\text { Outcome measures: } \\
\text { Need for surgery } \\
\text { Oswestry Disability } \\
\text { scores }\end{array}$ & $\begin{array}{l}\text { After } 6 \text { weeks, a significant dif- } \\
\text { ference was seen with improve- } \\
\text { ment in leg pain in the methyl- } \\
\text { prednisolone group. } \\
\text { After } 3 \text { months and } 12 \text { months, } \\
\text { there were no significant differ- } \\
\text { ences between groups. }\end{array}$ & $\begin{array}{l}\text { Positive short-term } \\
\text { and negative long- } \\
\text { term }\end{array}$ \\
\hline $\begin{array}{l}\text { Snoek et al (66) } \\
\text { Randomized trial } \\
\text { AHRQ Score } \\
7 / 10 \\
\text { Cochrane Score } \\
6 / 10\end{array}$ & $\begin{array}{l}51 \text { patients with lumbar root } \\
\text { compression documented } \\
\text { by neurological deficit and } \\
\text { a concordant abnormality } \\
\text { noted on myelography. } \\
\text { Experimental group : } 27 \\
\text { Control group : } 24\end{array}$ & $\begin{array}{l}\text { Experimental group: } \\
80 \mathrm{mg} \text { of methylpred- } \\
\text { nisolone }(2 \mathrm{~mL}) . \\
\text { Control group: } 2 \mathrm{~mL} \\
\text { of normal saline } \\
\text { Frequency: single } \\
\text { injection. }\end{array}$ & $\begin{array}{l}\text { Timing: } 3 \text { days and } \\
\text { an average of } 14 \\
\text { months } \\
\text { Outcome measures: } \\
\text { Pain, sciatic nerve } \\
\text { stretch tolerance, } \\
\text { subjective improve- } \\
\text { ment, surgical treat- } \\
\text { ment. }\end{array}$ & $\begin{array}{l}\text { No statistically significant differ- } \\
\text { ences were noted in either group } \\
\text { with regards to low back pain, } \\
\text { sciatic nerve stretch tolerance, } \\
\text { subjective improvement, and } \\
\text { surgical treatment. }\end{array}$ & $\begin{array}{l}\text { Negative short- } \\
\text { term and long- } \\
\text { term }\end{array}$ \\
\hline $\begin{array}{l}\text { Cuckler et al (51) } \\
\text { Randomized double } \\
\text { blind trial } \\
\text { AHRQ Score - 9/10 } \\
\text { Cochrane Score } \\
\text { 9/10 }\end{array}$ & $\begin{array}{l}73 \text { patients with back pain } \\
\text { due to either acute herniated } \\
\text { nucleus pulposus or spinal } \\
\text { stenosis of }>6 \text { months. } \\
\text { Experimental group }=42 \\
\text { Control group }=31\end{array}$ & $\begin{array}{l}\text { Experimental: } 80 \mathrm{mg} \\
(2 \mathrm{~mL}) \text { of methyl- } \\
\text { prednisolone }+5 \mathrm{~mL} \\
\text { of procaine } 1 \% . \\
\text { Control group: } 2 \mathrm{~mL} \\
\text { saline }+5 \mathrm{~mL} \text { of pro- } \\
\text { caine } 1 \% .\end{array}$ & $\begin{array}{l}\text { Timing: } 24 \text { hours } \\
\text { and an average of } 20 \\
\text { months } \\
\text { Outcome measures: } \\
\text { subjective improve- } \\
\text { ment. Need for } \\
\text { surgery. }\end{array}$ & $\begin{array}{l}\text { There was no significant short- } \\
\text { term or long-term improvement } \\
\text { among both groups. }\end{array}$ & $\begin{array}{l}\text { Negative short- } \\
\text { term and long- } \\
\text { term }\end{array}$ \\
\hline $\begin{array}{l}\text { Dilke et al (52) } \\
\text { Randomized trial } \\
\text { AHRQ Score } \\
7 / 10 \\
\text { Cochrane Score } \\
7 / 10 \\
\end{array}$ & $\begin{array}{l}100 \text { patients with low back } \\
\text { pain and sciatica of } 1 \text { week to } \\
\text { more than } 2 \text { yrs. } \\
\text { Experimental group: } 51 \\
\text { Control group: } 48\end{array}$ & $\begin{array}{l}\text { Experimental group: } \\
10 \mathrm{~mL} \text { of saline }+80 \\
\text { mg of methylpred- } \\
\text { nisolone. } \\
\text { Control group: } 1 \mathrm{~mL} \\
\text { of saline. }\end{array}$ & $\begin{array}{l}\text { Timing: } 2 \text { weeks and } \\
3 \text { months } \\
\text { Outcome measures: } \\
\text { pain relief, con- } \\
\text { sumption of analge- } \\
\text { sics and resumption } \\
\text { of work }\end{array}$ & $\begin{array}{l}\text { Initial Improvement: } 60 \% \text { in } \\
\text { the treatment group and } 31 \% \text { in } \\
\text { the control group. } \\
\text { A greater proportion of actively } \\
\text { treated patients improved at } 3 \\
\text { months. }\end{array}$ & $\begin{array}{l}\text { Positive short-term } \\
\text { and long-term }\end{array}$ \\
\hline $\begin{array}{l}\text { Ridley et al (56) } \\
\text { Randomized trial } \\
\text { AHRQ Score } \\
\text { 9/10 } \\
\text { Cochrane Score } \\
\text { 8/10 }\end{array}$ & $\begin{array}{l}35 \text { patients with low back } \\
\text { pain and sciatica of mean } \\
\text { duration approximately } 8 \\
\text { months. } \\
\text { Experimental group }=19 \\
\text { Control group }=16\end{array}$ & $\begin{array}{l}\text { Experimental group: } \\
10 \mathrm{~mL} \text { of saline }+80 \\
\text { mg of methylpred- } \\
\text { nisolone ( } \mathrm{n}=19) \text {. } \\
\text { Control group: saline } \\
2 \mathrm{~mL} \text {, interspinous } \\
\text { ligament }(\mathrm{n}=16) .\end{array}$ & $\begin{array}{l}\text { Timing: } 1 \text { week, } 2 \\
\text { weeks, } 3 \text { months } \\
\text { and } 6 \text { months } \\
\text { Outcome mea- } \\
\text { sures: pain control } \\
\text { improvement in } \\
\text { straight leg raising }\end{array}$ & $\begin{array}{l}90 \% \text { of the patients in the } \\
\text { treated group compared to } 19 \% \\
\text { in the control group showed } \\
\text { improvement at } 1 \text { week, } 2 \text { weeks } \\
\text { and } 12 \text { weeks. } \\
\text { By } 24 \text { weeks, the relief deterio- } \\
\text { rated to pre-treatment levels. }\end{array}$ & $\begin{array}{l}\text { Positive short-term } \\
\text { and negative long- } \\
\text { term }\end{array}$ \\
\hline $\begin{array}{l}\text { Rogers et al (57) } \\
\text { Randomized single } \\
\text { blind sequential } \\
\text { analysis } \\
\text { AHRQ Score- } 6 / 10 \\
\text { Cochrane Score } 5 / 10\end{array}$ & $\begin{array}{l}30 \text { patients with low back } \\
\text { pain. } \\
\text { Experimental group }=15 \\
\text { Control group }=15\end{array}$ & $\begin{array}{l}\text { Experimental group: } \\
\text { local anesthetic }+ \\
\text { steroid. } \\
\text { Control group: local } \\
\text { anesthetic alone. }\end{array}$ & $\begin{array}{l}\text { Timing: } 1 \text { month } \\
\text { Outcome measures: } \\
\text { pain relief and nerve } \\
\text { root tension signs }\end{array}$ & $\begin{array}{l}\text { Experimental group significant- } \\
\text { ly better results. } \\
\text { Long-term results were similar } \\
\text { for both. }\end{array}$ & $\begin{array}{l}\text { Positive short-term } \\
\text { relief and negative } \\
\text { long-term }\end{array}$ \\
\hline $\begin{array}{l}\text { Kraemer et al }(61) \\
\text { Randomized trial } \\
\text { AHRQ score: } 6 / 10 \\
\text { Cochrane score: } 5 / 10\end{array}$ & $\begin{array}{l}\text { Control }=46 \\
\text { Intervention }=40\end{array}$ & $\begin{array}{l}\text { Control :paraverte- } \\
\text { bral local injection of } \\
\text { local anesthetic, with } \\
\text { intramusclar steroid } \\
\text { injection. } \\
\text { Intervention group : } \\
\text { lumbar interlaminar } \\
\text { steroid injection. }\end{array}$ & $\begin{array}{l}\text { Timing: } 3 \text { weeks, } \\
\text { and } 3 \text { months } \\
\text { Pain relief }\end{array}$ & $\begin{array}{l}\text { Epidural injections were more } \\
\text { effective than paravertebral } \\
\text { injections. } \\
\text { Epidural perineural injections } \\
\text { were more effective than con- } \\
\text { ventional posterior epidural } \\
\text { injections. }\end{array}$ & $\begin{array}{l}\text { Positive short-term } \\
\text { and negative long- } \\
\text { term }\end{array}$ \\
\hline $\begin{array}{l}\text { Pirbudak et al (68) } \\
\text { Randomized non } \\
\text { blinded } \\
\text { AHRQ score: } 7 / 9 \\
\text { Cochrane score: } 6 / 10\end{array}$ & $\begin{array}{l}92 \text { patients with sciatica. } \\
\text { Experimental with steroids } \\
\text { and amitriptyline }=46 \\
\text { Control with steroids }=46\end{array}$ & $\begin{array}{l}\text { Experimental:benz- } \\
\text { ylprednisolone ( } 14 \\
\text { mg) + bupivacaine } \\
\text { and } 10-50 \text { mg oral } \\
\text { amitryptiline. } \\
\text { Control; benzylpred- } \\
\text { nisolone and bupi- } \\
\text { vacaine. }\end{array}$ & $\begin{array}{l}\text { Timing: } 2 \text { weeks, } \\
6 \text { weeks and } 9 \\
\text { months. } \\
\text { Outcome measures: } \\
\text { VAS and Oswestry } \\
\text { low back pain dis- } \\
\text { ability questionnaire }\end{array}$ & $\begin{array}{l}\text { Lumbar epidural steroid injec- } \\
\text { tion reported pain relief up to } \\
6 \text { months. Additional oral ami- } \\
\text { tryptiline increased pain relief to } \\
9 \text { months. }\end{array}$ & $\begin{array}{l}\text { Positive short- } \\
\text { term and long- } \\
\text { term }\end{array}$ \\
\hline $\begin{array}{l}\text { McGregor et al (69) } \\
\text { AHRQ Score } \\
6 / 10 \\
\text { Cochrane score: } 5 / 10\end{array}$ & $\begin{array}{l}44 \text { patients with low back } \\
\text { and leg pain }\end{array}$ & $\begin{array}{l}\text { Caudal epidural vs } \\
\text { lumbar epidural. }\end{array}$ & Visual analog scale & $\begin{array}{l}\text { There were no significant } \\
\text { differences between the } \\
\text { techniques. }\end{array}$ & $\begin{array}{l}\text { Negative short } \\
\text { term and long } \\
\text { term }\end{array}$ \\
\hline
\end{tabular}


Table 3. Characteristics of published randomized trials of cervical interlaminar epidural injections

\begin{tabular}{|c|c|c|c|c|c|}
\hline Study/Methods & Participants & Intervention(s) & Outcome(s) & Result(s) & Conclusion(s) \\
\hline & & & & \multicolumn{2}{|c|}{$\begin{array}{c}\text { Short-term relief }<6 \mathrm{wks} \\
\text { Long-term relief } \geq 6 \mathrm{wks}\end{array}$} \\
\hline $\begin{array}{l}\text { Castagnera et al } \\
(58) \\
\text { Randomized trial with } \\
\text { cervical interlaminar } \\
\text { epidural steroid injections } \\
\text { AHRQ Score }-7 / 10 \\
\text { Cochrane Score } 6 / 10\end{array}$ & $\begin{array}{l}\text { 14- local anesthetic } \\
\text { and steroid } \\
10 \text { local anesthetic, } \\
\text { steroid + morphine } \\
\text { sulfate }\end{array}$ & $\begin{array}{l}\text { i. } 0.5 \% \text { lidocaine }+ \text { tri- } \\
\text { amcinolone acetonide } \\
\text { ii. Local anesthetic }+ \\
\text { steroid }+2.5 \text { mg of mor- } \\
\text { phine sulfate }\end{array}$ & $\begin{array}{l}\text { Timing: } 1 \text { month, } 3 \\
\text { months, and } 12 \text { months } \\
\text { Outcome measures: pain } \\
\text { relief }\end{array}$ & $\begin{array}{l}\text { The success rate was } \\
79 \% \text { vs. } 80 \% \text { in group } \\
\text { I and II. } \\
\text { Overall, initial success } \\
\text { rate was } 96 \%, 75 \% \\
\text { at } 1 \text { month, } 79 \% \text { at } 3 \\
\text { months, } 6 \text { months, and } \\
12 \text { months. }\end{array}$ & $\begin{array}{l}\text { Positive short- } \\
\text { term and long- } \\
\text { term }\end{array}$ \\
\hline $\begin{array}{l}\text { Stav et al (63) } \\
\text { Randomized trial of } \\
\text { cervical epidural steroid } \\
\text { injections } \\
\text { AHRQ Score - } 6 / 10 \\
\text { Cochrane Score - } 5 / 10\end{array}$ & $\begin{array}{l}\text { Experimental }=25 \\
\text { Control }=17\end{array}$ & $\begin{array}{l}\text { Experimental group: cer- } \\
\text { vical epidural steroid and } \\
\text { lidocaine injections } \\
\text { Control group: steroid } \\
\text { and lidocaine injections } \\
\text { into the posterior neck } \\
\text { muscles }\end{array}$ & $\begin{array}{l}\text { Timing: one week and } \\
\text { one year } \\
\text { Outcome measures: pain } \\
\text { relief, change in range of } \\
\text { motion, reduction of daily } \\
\text { dose of analgesics, return } \\
\text { to work }\end{array}$ & $\begin{array}{l}\text { One week improve- } \\
\text { ment } 36 \% \text { vs } 76 \% \\
\text { One year improvement } \\
12 \% \text { vs } 68 \%\end{array}$ & $\begin{array}{l}\text { Positive short- } \\
\text { term and long- } \\
\text { term }\end{array}$ \\
\hline
\end{tabular}

ple other observational trials (78-106).

\section{Methodological Criteria}

Of the randomized trials, 11 studie met inclusion criteria $(51,52,56-58,61$, $63-65,68,69)$. One study (53) was excluded as they studied effects of subarachnoid and epidural midazolam. Two studies (59, 60) focused on diabetic polyneuropathy and intractable post herpetic neuralgia. One study (64) evaluated only inpatients, whereas 4 evaluations $(54,55,61,67)$ failed to evaluate long-term relief, and, finally, one study (62) was not included due to lack of data for review. Tables $2 \& 3$ illustrate various characteristics and results of published randomized trials meeting inclusion criteria.

Of the 9 non-randomized prospective trials, only 3 studies (70-78) met the criteria for inclusion.

\section{Effectiveness}

Of the 9 randomized trials $(51,52$, $56,57,65-69)$ included in the evaluation of lumbar radiculitis, 5 were positive for short-term relief $(52,56-58,65)$, whereas only one study was positive for long-term relief (52). Among the 3 prospective evaluations included for evaluating low back and lower extremity pain $(71,72,74)$, two studies were positive for short-term relief $(71,74)$ whereas one was positive for long-term relief (71)

Among the other prospective evaluations, a study evaluating management of lumbar radiculopathy (72), a study evaluating effect in spinal stenosis (75), another study evaluating and comparing single caudal injection with interlaminar injection (69), and another study evaluating correlation of epidural steroid injection as a predictor of surgical outcome (77), were all shown to be negative.

In the evaluation of cervical pain and radiculopathy, two randomized trials (58, 63 ), one prospective evaluation (70), and multiple retrospective evaluations were available (78-89). Both the randomized trials $(58,63)$ evaluating the effectiveness of interlaminar cervical epidural steroids in managing cervical radiculopathy were positive. The single prospective evaluation of the cervical spine (70) was not included as all the patients who underwent interlaminar epidural steroid injections also underwent transforaminal epidural steroid injections.

Of the 3 randomized trials, which were positive, Dilke et al (52) studied low back pain and sciatica, whereas Castagnera et al (58) and Stav et al (63) studied chronic cervical radicular pain. Cuckler et al (51) also included post lumbar laminectomy syndrome patients with overall negative results. Due to a multitude of randomized trials and the availability of double blind or randomized, and prospective trials, evidence from retrospective trials was not included.

\section{Level of Evidence}

In managing lumbar radicular pain with interlaminar lumbar epidural steroid injections, the level of evidence was strong for short-term relief and limited for long-term relief. In managing cervical radiculopathy with cervical interlam- inar epidural steroid injections, the evidence was moderate for short-term improvement and long-term improvement. However, the evidence was inconclusive in the management of axial neck pain, axial low back pain, and lumbar spinal stenosis with lumbar or cervical interlaminar epidural steroid injections.

\section{Transforaminal Epidural Injections}

Our search strategy yielded a total of 189 publications. Relevant reports evaluating the effectiveness of transforaminal epidural injections included 8 randomized trials $(61,107-113), 14$ prospective evaluations $(70,114-126)$, and multiple retrospective reports (127-141). Table 4 shows study characteristics of randomized trials evaluating transforaminal epidural steroid injections, along with methodological criteria, whereas, Table 5 shows descriptions of non-randomized studies.

\section{Description of Study Characteristics}

All the randomized evaluations studied the effect of transforaminal epidural steroid injections in lumbar radiculitis with disc herniation except Devulder et al (110), studying the effectiveness of transforaminal epidural steroid injections in post lumbar laminectomy syndrome.

Riew et al (107) evaluated transforaminal epidural steroid injections and local anesthetic injections in patients with either a disc herniation or central or lateral stenosis. They studied the number of patients avoiding surgical intervention. Karppinen et al $(108,109)$ evaluated transforaminal epidural steroid injec- 
tions, in patients with MRI-confirmed herniated nucleus pulposus. The outcome measures were $50 \%$ relief of leg pain and cost effectiveness. Vad et al (112) evaluated transforaminal epidural steroid injections and compared them to patients undergoing lumbar paraspinal trigger point injections with sodium chloride solution. The outcome measures included improvement in leg pain, Roland-Morris score, and patient satisfaction score.

Thomas et al (113) evaluated the effectiveness of transforaminal epidural and compared it with interspinous corticosteroid injection. Devulder et al (110) used a combination of methylprednisolone, bupivacaine, and hyaluronidase and compared this to a combination of sodium chloride solution, bupivacaine, and hyaluronidase. The outcome measures were reduction in leg pain of at least $50 \%$.

\section{Methodological Criteria}

Among the 8 randomized controlled trials, only 5 trials $(107,109,110,112$, 113) met the criteria for inclusion (Table 4). The trial by Kolsi et al (111) was not included since the measurements were only of short-term duration. Karppinen et al $(108,109)$ used two publications to report the results of one trial. Kraemer et al (61) described lumbar epidural perineural injection, however, using an interlaminar approach, a non-validated technique.

Among the 14 prospective evaluations $(70,114-126), 6$ were included (70, $114,121-123,126)$. Characteristics of the observational studies are described in Table 4 .

\section{Effectiveness}

Among the 5 randomized trials included in the evidence synthesis meeting inclusion criteria (Table 3), 4 of them evaluated the effectiveness of lumbar disc herniation and radiculopathy $(107,109$, $112,113)$, whereas, one study (110) evaluated the response in post lumbar laminectomy syndrome. Three of the four studies showed positive results with short-term and long-term improvement. The study in postlumbar laminectomy syndrome was negative.

Among the 6 prospective evaluations included in the study, 2 studies evaluated the effectiveness of cervical transforaminal epidurals $(70,123)$, showing positive results. The remaining 4 prospective studies included patients with low back and lower extremity pain. One study also evaluated lumbar disc herniation regression after successful epidural steroid injection (120). A second study (122) compared effectiveness of transforaminal epidural steroid injections in the lumbar spine with discectomy. All the prospective evaluations showed positive short-term and long-term results. Multiple retrospective evaluations also showed positive results. Due to the significant number of publications available in the English literature with randomized and prospective designs, retrospective evaluations were not included in the evidence synthesis.

\section{Level of Evidence}

The evidence for lumbar transforaminal epidural steroid injections in managing lumbar nerve root pain was strong for short-term and moderate for long-term improvement. The evidence for cervical transforaminal epidural steroid injections in managing cervical nerve root pain, was moderate for short-term and long-term improvement. The evidence was limited in managing lumbar radicular pain in post lumbar laminectomy syndrome. The evidence of lumbar transforaminal epidural steroid injections in managing lumbar spinal stenosis was limited. The evidence was indeterminate in managing axial low back pain, axial neck pain, and lumbar disc extrusions.

\section{Caudal Epidural Injections}

Our search strategy yielded a total of 232 articles. Relevant reports studying caudal epidural injections included 9 randomized (142-149), 5 prospective evaluations $(69,150-153,156)$, and multiple retrospective evaluations $(1,154,155)$. The results of published reports of the randomized trials are described in Table 6, while Table 7 shows descriptions of prospective evaluations.

\section{Methodological Quality}

Of the 9 randomized trials, 2 trials were excluded. One study (146) was excluded due to non-availability of analyzable information, whereas a second trial (145) was excluded due to lack of longterm data.

Of the 7 randomized trials, 3 trials evaluated predominantly patients with radiculopathy or sciatica (142-144), 2 trials evaluated patients suffering with pain following failed back surgery syndrome $(148,149)$, and, one study (147) evaluated a mixed population with $50 \%$ post lumbar laminectomy syndrome patients.
One study (69) compared blind interlaminar epidurals with caudal epidural steroid injections.

Among the 5 non-randomized evaluations (150-153, 156), radiculopathy or sciatica patients were studied in 2 evaluations $(152,153)$, the role of caudal epidural in chronic low back pain was studied in an additional 2 studies $(150,151)$, and the role of caudal epidural steroids was studied in spinal stenosis in one study (156).

\section{Effectiveness}

Of the 7 randomized trials, 4 were positive for short-term pain relief (142, $143,147,148)$, and 3 were positive for long-term relief $(142,144,147)$.

Among 7 randomized trials included for analysis, of the 4 trials evaluating predominantly radiculopathy, 2 were positive $(142,143)$ and 2 studies were negative $(69$, 144) for short-term relief, whereas 2 of 3 were positive for long-term relief (142, 144). Of the two studies with postlumbar laminectomy syndrome $(148,149)$, only one study (148) was positive for shortterm. One study (147) included patients with sciatica, as well as post lumbar laminectomy syndrome. This study showed positive results, both for short-term and long-term.

Among the prospective studies, 2 studies evaluating radiculopathy or sciatica $(152,153)$, and 2 studies evaluating the effectiveness of caudal epidural steroid injections in chronic low back pain (150, 151 ), were positive, and one study evaluating the effectiveness of caudal in lumbar spinal stenosis was positive.

\section{Level of Evidence}

Overall, 3 of the 5 randomized trials were positive for pain of radiculopathy, and 2 of 3 were positive for post lumbar laminectomy syndrome among randomized trials.

Among the prospective evaluations, 4 of the 5 studies evaluating radicular pain or low back pain were positive.

Thus, positive long-term relief trials was $60 \%$ for radiculopathy or sciatica and $67 \%$ for post lumbar laminectomy syndrome. Among the prospective evaluations, $80 \%$ were positive for radiculopathy and chronic low back pain.

The evidence of caudal epidural steroid injections with randomized trials and non-randomized reports is strong for short-term relief and moderate for longterm relief, in managing chronic pain of lumbar radiculopathy and post lumbar 
Table 4. Details of randomized trials studying the effectiveness of lumbar transforaminal epidural steroid injections

\begin{tabular}{|c|c|c|c|c|c|}
\hline Study/Methods & Participants & Intervention(s) & Outcome(s) & Result(s) & Conclusion(s) \\
\hline & & & & & $\begin{array}{r}\text { Short-term } \\
\text { relief }<6 \mathrm{wks} \\
\text { Long-term } \\
\text { relief } \geq 6 \mathrm{wk}\end{array}$ \\
\hline $\begin{array}{l}\text { Riew et al (107) } \\
\text { Randomized } \\
\text { double blind trial } \\
\text { AHRQ Score } \\
8 / 10 \\
\text { Cochrane Score } \\
7 / 10\end{array}$ & $\begin{array}{l}55 \text { patients with lumbar } \\
\text { disc herniations or spi- } \\
\text { nal stenosis referred for } \\
\text { surgical evaluation. } \\
\text { All pts. had failed a min- } \\
\text { imum of } 6 \text { weeks of } \\
\text { conservative care or had } \\
\text { unrelenting pain. } \\
28 \text { patients in experi- } \\
\text { mental group } \\
27 \text { patients in control } \\
\text { group }\end{array}$ & $\begin{array}{l}\text { Experimental group: transforaminal } \\
\text { nerve root or epidural steroid injection } \\
\text { with } 1 \mathrm{~mL} \text { of } 0.25 \% \text { bupivacaine and } 6 \\
\text { mg of betamethasone } \\
\text { Control group: } 1 \mathrm{~mL} \text { of } 0.25 \% \text { bupi- } \\
\text { vacaine. } \\
\text { The patient was allowed to choose to } \\
\text { receive as many as } 4 \text { injections at any } \\
\text { time during the follow-up. }\end{array}$ & $\begin{array}{l}\text { Timing: } 1 \text { year } \\
\text { Outcome measures: } \\
\text { Injections were } \\
\text { considered to have } \\
\text { failed if the patient } \\
\text { opted for operative } \\
\text { treatment. } \\
\text { North American } \\
\text { Spine Society ques- } \\
\text { tionnaire. }\end{array}$ & $\begin{array}{l}\text { Of the } 28 \text { patients in the experimen- } \\
\text { tal group with bupivacaine and beta- } \\
\text { methasone, } 20 \text { decided not to have the } \\
\text { operation. } \\
\text { Of the } 27 \text { patients in the control group } \\
\text { receiving bupivacaine alone, } 9 \text { elected } \\
\text { not to have the operation. They had } \\
\text { highly significant pain relief and func- } \\
\text { tional improvement. }\end{array}$ & $\begin{array}{l}\text { Positive short- } \\
\text { term and long- } \\
\text { term }\end{array}$ \\
\hline $\begin{array}{l}\text { Karppinen et al } \\
(108,109) \\
\text { Randomized } \\
\text { double blind trial } \\
\text { AHRQ Score } \\
9 / 10 \\
\text { Cochrane Score } \\
8 / 10\end{array}$ & $\begin{array}{l}160 \text { consecutive, eligi- } \\
\text { ble patients with sciati- } \\
\text { ca with unilateral symp- } \\
\text { toms of } 1 \text { to } 6 \text { months } \\
\text { duration. } \\
\text { None of the patients } \\
\text { have undergone surgery. }\end{array}$ & $\begin{array}{l}\text { Experimental group: } \\
\text { local anesthetic and methylprednis- } \\
\text { olone } \\
\text { Control group: normal saline }\end{array}$ & $\begin{array}{l}\text { Timing: } 2 \text { weeks, } 3 \\
\text { months, } 6 \text { months } \\
\text { Outcome measures: } \\
\text { Pain relief, sick } \\
\text { leave, medical costs, } \\
\text { and future surgery. } \\
\text { Nottingham Health } \\
\text { Profile }\end{array}$ & $\begin{array}{l}\text { In the case of contained herniations, the } \\
\text { steroid injection produced significant } \\
\text { treatment effects and short-term in leg } \\
\text { pain, straight leg raising, disability and } \\
\text { in Nottingham Health Profile, emotion- } \\
\text { al reactions and cost effectiveness. }\end{array}$ & $\begin{array}{l}\text { Negative short- } \\
\text { term and long- } \\
\text { term }\end{array}$ \\
\hline $\begin{array}{l}\text { Vad et al (112) } \\
\text { A prospective } \\
\text { study randomized } \\
\text { by patient choice } \\
\text { from the private } \\
\text { practice of a single } \\
\text { physician. } \\
\text { AHRQ Score } \\
\text { 7/10 } \\
\text { Cochrane Score } \\
7 / 10\end{array}$ & $\begin{array}{l}\text { Patients with leg pain, } \\
\text { older than } 18 \text { years, } \\
\text { had been symptomat- } \\
\text { ic longer than } 6 \text { weeks, } \\
\text { had undergone a lum- } \\
\text { bar spine magnetic res- } \\
\text { onance imaging scan } \\
\text { documenting herni- } \\
\text { ated nucleus pulpo- } \\
\text { sus or manifested clini- } \\
\text { cal signs such as radic- } \\
\text { ular pain with lumbar } \\
\text { radiculopathy. }\end{array}$ & $\begin{array}{l}\text { Experimental group: transforaminal } \\
\text { epidural steroid injection. } 1.5 \mathrm{~mL} \text { each } \\
\text { of betamethasone acetate, } 9 \mathrm{mg} \text { and } 2 \% \\
\text { preservative-free Xylocaine per level. } \\
\text { Control group: trigger point injec- } \\
\text { tions. All patients received a self-direct- } \\
\text { ed home lumbar stabilization program } \\
\text { consisting of four simple exercises em- } \\
\text { phasizing hip and hamstring flexibility } \\
\text { and abdominal and lumbar paraspinal } \\
\text { strengthening. }\end{array}$ & $\begin{array}{l}\text { Timing: } 3 \text { weeks, } 6 \\
\text { weeks, } 3 \text { months, } \\
6 \text { months, and } 12 \\
\text { months. } \\
\text { Outcome measures: } \\
\text { Roland-Morris } \\
\text { score, visual nu- } \\
\text { meric score, finger- } \\
\text { to-floor distance, } \\
\text { patient satisfaction } \\
\text { score. }\end{array}$ & $\begin{array}{l}\text { Fluoroscopically guided transforaminal } \\
\text { epidural steroid injections yielded bet- } \\
\text { ter results compared to saline trigger } \\
\text { point injections. } \\
\text { The group receiving transforaminal } \\
\text { epidural steroid injections had a success } \\
\text { rate of } 84 \% \text {, as compared with the } 48 \% \\
\text { for the group receiving trigger point in- } \\
\text { jections. }\end{array}$ & $\begin{array}{l}\text { Positive short- } \\
\text { term and long- } \\
\text { term }\end{array}$ \\
\hline $\begin{array}{l}\text { Devulder (110) } \\
\text { AHRQ Score } \\
6 / 10 \\
\text { Cochrane Score } \\
5 / 10\end{array}$ & $\begin{array}{l}\text { An open, nonblinded, } \\
\text { randomized study on } \\
60 \text { patients with docu- } \\
\text { mented fibrosis in fewer } \\
\text { than three nerve roots. }\end{array}$ & $\begin{array}{l}\text { Group A }=20 \text { patients were injected } \\
\text { with } 1 \mathrm{ml} \text { bupivacaine } 0.5 \% \text { combined } \\
\text { with } 1500 \text { units hyaluronidase and } 1 \mathrm{ml} \\
\text { saline per nerve root sleeve } \\
\text { Group B }=20 \text { were treated with } 1 \mathrm{ml} \\
\text { bupivacaine } 0.5 \% \text { combined with } \\
40 \mathrm{mg} \text { methylprednisolone solution } \\
\text { (Depo Medrol) per nerve root } \\
\text { Group C; was treated with bupivacaine } \\
0.5 \% \text { combined with } 1500 \text { units hyal- } \\
\text { uronidase and } 40 \text { mg methylpredniso- } \\
\text { lone solution. The volume of each in- } \\
\text { jection was } 2 \text { ml. and were given twice } \\
\text { at an interval of } 1 \text { wkeek. }\end{array}$ & $\begin{array}{l}\text { The patients were } \\
\text { evaluated on a ver- } \\
\text { bal pain rating scale } \\
1,3 \text {, and } 6 \text { months } \\
\text { after the second in- } \\
\text { jection. The Krus- } \\
\text { kal-Wallis test was } \\
\text { used to detect sta- } \\
\text { tistically significant } \\
\text { differences among } \\
\text { the three groups, } \\
\text { and the analysis was } \\
\text { refined with the } \\
\text { Friedman test. }\end{array}$ & $\begin{array}{l}\text { Overall, although injections induced } \\
\text { analgesia at } 1 \text { month, these effects were } \\
\text { reduced at } 3 \text { - and } 6 \text {-month follow-ups. } \\
\text { No statistical differences were found be- } \\
\text { tween the three treatment groups (af- } \\
\text { ter } 1 \text { month, } \mathrm{p}=0.71 \text {; after } 3 \text { months, } \\
\mathrm{p}=0.69 \text {; after } 6 \text { months, } \mathrm{p}=0.66 \text {. The } \\
\text { Friedman test showed a significant de- } \\
\text { crease in treatment score as a function } \\
\text { of time in groups B and } \mathrm{C}(\mathrm{p}=0.015) \\
\text { but not in group A ( } \mathrm{p}=0.074) \text {. Corti- } \\
\text { costeroids seem responsible for the last } \\
\text { phenomenon. }\end{array}$ & $\begin{array}{l}\text { Negative short- } \\
\text { term and long- } \\
\text { term }\end{array}$ \\
\hline $\begin{array}{l}\text { Thomas (113) } \\
\text { AHRQ Score } \\
6 / 10 \\
\text { Cochrane Score } \\
5 / 10\end{array}$ & $\begin{array}{l}\text { Thirty-one patients ( } 18 \\
\text { females, } 13 \text { males) with } \\
\text { discal radicular pain of } \\
\text { less than } 3 \text { months' du- } \\
\text { ration }\end{array}$ & $\begin{array}{l}\text { Patients were consecutively random- } \\
\text { ized to receive either radio-guided } \\
\text { transforaminal or blindly performed } \\
\text { interspinous epidural corticosteroid } \\
\text { injections. }\end{array}$ & $\begin{array}{l}\text { Post-treatment out- } \\
\text { come was evaluated } \\
\text { clinically at } 6 \text { and } \\
30 \text { days, and then at } \\
6 \text { months, but only } \\
\text { by mailed question- } \\
\text { naire. }\end{array}$ & $\begin{array}{l}\text { At day } 6 \text {, the between-group difference } \\
\text { was significantly in favor of the transfo- } \\
\text { raminal group with respect to Schober's } \\
\text { index, finger-to-floor distance, dai- } \\
\text { ly activities, and work and leisure ac- } \\
\text { tivities on the Dallas pain scale. At day } \\
\text { 30, pain relief was significantly better } \\
\text { in the transforaminal group. At month } \\
6 \text {, answers to the mailed questionnaire } \\
\text { still showed significantly better results } \\
\text { for transforaminal injection concern- } \\
\text { ing pain, daily activities, work and lei- } \\
\text { sure activities and anxiety and depres- } \\
\text { sion, with a decline in the Roland-Mor- } \\
\text { ris score. }\end{array}$ & $\begin{array}{l}\text { Positive short- } \\
\text { term and long- } \\
\text { term }\end{array}$ \\
\hline
\end{tabular}


Table 5. Details and results of non-randomized trials of transforaminal epidural injections

\begin{tabular}{|c|c|c|c|c|c|}
\hline Study/Methods & Participants & Intervention(s) & Outcome(s) & Result(s) & Conclusion(s) \\
\hline Lumbar Spine & & & & \multicolumn{2}{|c|}{$\begin{array}{l}\text { Short-term relief }<6 \mathrm{wks} \\
\text { Long-term relief } \geq 6 \mathrm{wks}\end{array}$} \\
\hline $\begin{array}{l}\text { Lutz et al (114) } \\
\text { A prospective case } \\
\text { series. } \\
\text { AHRQ Score } \\
4 / 8\end{array}$ & $\begin{array}{l}69 \text { patients with } \\
\text { lumbar herniated } \\
\text { nucleus pulposus and } \\
\text { radiculopathy were } \\
\text { recruited. Every patient } \\
\text { in the case series had } \\
\text { documented MRI } \\
\text { findings that showed disc } \\
\text { herniation with nerve } \\
\text { root compression. }\end{array}$ & $\begin{array}{l}\text { Transforaminal } \\
\text { epidural steroid } \\
\text { injections with } 1.5 \mathrm{cc} \\
\text { of } 2 \% \text { Xylocaine and } 9 \\
\text { mg of betamethasone } \\
\text { acetate. }\end{array}$ & $\begin{array}{l}\text { Timing: } 28 \text { to } 144 \text { weeks } \\
\text { Outcome measures: At least } \\
\pm 50 \% \text { reduction in pre- } \\
\text { injection and post-injection } \\
\text { visual numerical pain scores. }\end{array}$ & $\begin{array}{l}\text { A successful outcome was } \\
\text { reported by } 52 \text { of the } 69 \\
\text { patients ( } 75.4 \% \text { ) at an average } \\
\text { follow-up of } 80 \text { weeks (range } \\
28 \text { - } 144 \text { weeks). }\end{array}$ & $\begin{array}{l}\text { Positive short- } \\
\text { term and long- } \\
\text { term }\end{array}$ \\
\hline $\begin{array}{l}\text { Butterman (121) } \\
\text { Prospective evaluation } \\
\text { AHRQ Score } \\
4 / 8\end{array}$ & $\begin{array}{l}232 \text { patients who were } \\
\text { referred for treatment } \\
\text { of DDD } \\
171 \text { patients who } \\
\text { were possible spinal } \\
\text { arthrodesis candidates. }\end{array}$ & $\begin{array}{l}\text { Transforaminal } \\
\text { epidural steroid } \\
\text { injections or } \\
\text { Intradiscal steroid } \\
\text { injections (ISIs) }\end{array}$ & $\begin{array}{l}\text { Pain and function were } \\
\text { determined by a self- } \\
\text { administered outcomes } \\
\text { questionnaire that consisted } \\
\text { of a visual analog pain scale, } \\
\text { pain drawing, Oswestry } \\
\text { Disability Index, use of pain } \\
\text { medication and opinion of } \\
\text { treatment success. }\end{array}$ & $\begin{array}{l}\text { ESI was effective in improving } \\
\text { pain and function, as assessed } \\
\text { by outcomes scores at short- } \\
\text { term follow-up. However, at } \\
2 \text { years, less than one-third } \\
\text { had not had additional } \\
\text { invasive treatment. Patients } \\
\text { with inflammatory end- } \\
\text { plate changes had greater } \\
\text { improvement in the first } 6 \\
\text { months than did those patients } \\
\text { without the end-plate changes. }\end{array}$ & $\begin{array}{l}\text { Positive short- } \\
\text { term and long- } \\
\text { term }\end{array}$ \\
\hline $\begin{array}{l}\text { Butterman (122) } \\
\text { Prospective evaluation } \\
\text { AHRQ Score } \\
4 / 8\end{array}$ & $\begin{array}{l}169 \text { patients with a large } \\
\text { herniation of the lumbar } \\
\text { nucleus pulposus }\end{array}$ & $\begin{array}{l}\text { Transforaminal } \\
\text { epidural steroid } \\
\text { injection or discectomy }\end{array}$ & $\begin{array}{l}\text { Evaluation was performed } \\
\text { with the use of outcomes } \\
\text { scales and neurological } \\
\text { examination. }\end{array}$ & $\begin{array}{l}42 \% \text { to } 56 \% \text { of the fifty } \\
\text { patients who had epidural } \\
\text { steroid injection reported } \\
\text { that the treatment had been } \\
\text { effective. Patients who had } \\
\text { discectomy had the most rapid } \\
\text { decrease in symptoms, with } \\
92 \% \text { to } 98 \% \text { of the patients } \\
\text { reporting that the treatment } \\
\text { had been successful over the } \\
\text { various follow-up periods. }\end{array}$ & $\begin{array}{l}\text { Positive short- } \\
\text { term and long- } \\
\text { term }\end{array}$ \\
\hline $\begin{array}{l}\text { Botwin et al (126) } \\
\text { Prospective evaluation } \\
\text { AHRQ Score } \\
4 / 8\end{array}$ & $\begin{array}{l}34 \text { patients who met our } \\
\text { inclusion criteria for the } \\
\text { treatment of unilateral } \\
\text { radicular pain from } \\
\text { degenerative lumbar } \\
\text { spinal stenosis }\end{array}$ & $\begin{array}{l}\text { Fluoroscopically } \\
\text { guided lumbar } \\
\text { transforaminal } \\
\text { epidural injections. } \\
\text { The injectant } \\
\text { consisted of } 12 \mathrm{mg} \\
\text { of betamethasone } \\
\text { acetate and } 2 \mathrm{ml} \text { of } \\
1 \% \text { preservative-free } \\
\text { lidocaine HCL. }\end{array}$ & $\begin{array}{l}\text { Patients were evaluated by } \\
\text { an independent observer } \\
\text { and received questionnaires } \\
\text { before the initial injection, at } \\
2 \text { mo, and at } 12 \text { mo after the } \\
\text { injections. Questionnaires } \\
\text { included a visual analog } \\
\text { scale, Roland 5-point pain } \\
\text { scale, standing/walking } \\
\text { tolerance, and patient } \\
\text { satisfaction scale. }\end{array}$ & $\begin{array}{l}75 \% \text { of patients had successful } \\
\text { long-term outcome, reporting } \\
\text { at least a }>50 \% \text { reduction } \\
\text { between preinjection and } \\
\text { postinjection pain scores, with } \\
\text { an average of } 1.9 \text { injections per } \\
\text { patient. } 64 \% \text { of patients had } \\
\text { improved walking tolerance, } \\
\text { and } 57 \% \text { had improved } \\
\text { standing tolerance at } 12 \text { mo. }\end{array}$ & $\begin{array}{l}\text { Positive short- } \\
\text { term and long- } \\
\text { term }\end{array}$ \\
\hline \multicolumn{6}{|l|}{ Cervical Spine } \\
\hline $\begin{array}{l}\text { Bush and Hillier (70) } \\
\text { Prospective evaluation } \\
\text { AHRQ Score } \\
4 / 8\end{array}$ & $\begin{array}{l}68 \text { patients with neck } \\
\text { pain and cervical } \\
\text { radiculopathy. }\end{array}$ & $\begin{array}{l}\text { Transforaminal } \\
\text { cervical epidural } \\
\text { steroid injections }\end{array}$ & $\begin{array}{l}\text { Timing: } 1 \text { month to } 1 \text { year } \\
\text { Outcome measures: Pain } \\
\text { relief }\end{array}$ & $\begin{array}{l}93 \% \text { of the patients were } \\
\text { reported to have good pain } \\
\text { relief lasting for } 7 \text { months. }\end{array}$ & $\begin{array}{l}\text { Positive short- } \\
\text { term and long- } \\
\text { term }\end{array}$ \\
\hline $\begin{array}{l}\text { Cyteval (123) } \\
\text { AHRQ Score } \\
4 / 8\end{array}$ & $\begin{array}{l}30 \text { patients with cervical } \\
\text { radiculopathy } \\
16 \text { patients with } \\
\text { foraminal degenerative } \\
\text { stenosis } \\
14 \text { patients with disk } \\
\text { herniation }\end{array}$ & $\begin{array}{l}\text { Percutaneous } \\
\text { periradicular foraminal } \\
\text { steroid infiltration } \\
\text { under CT control }\end{array}$ & $\begin{array}{l}\text { The intensity of radicular } \\
\text { pain was scored on an } \\
\text { analogic visual scale (AVS). } \\
\text { Pain relief was classified as } \\
\text { excellent when the pain had } \\
\text { diminished by } 75 \% \text { or more; } \\
\text { good, by } 50 \%-74 \% \text {; fair by } \\
25 \%-49 \% \text {; or poor, by less } \\
\text { than } 25 \% \text {. The patients were } \\
\text { followed up at } 2 \text { weeks and at } \\
6 \text { months. }\end{array}$ & $\begin{array}{l}\text { Good pain relief was reported } \\
\text { in } 60 \% \text { of patients. There was } \\
\text { no rebound of pain at the } 6- \\
\text { month follow-up. }\end{array}$ & $\begin{array}{l}\text { Positive short- } \\
\text { term and long- } \\
\text { term }\end{array}$ \\
\hline
\end{tabular}


Table 6. Characteristics of published randomized trials of caudal epidural injections

\begin{tabular}{|c|c|c|c|c|c|}
\hline Study/Methods & Participants & Interventions & Outcomes & Results & $\begin{array}{l}\text { Outcomes/ } \\
\text { Conclusion }\end{array}$ \\
\hline & & & & & $\begin{array}{l}\text { Short-term relief }<6 \mathrm{wks} \\
\text { Long-term relief } \geq 6 \mathrm{wk}\end{array}$ \\
\hline $\begin{array}{l}\text { McGregor et al (69) } \\
\text { AHRQ Score } \\
6 / 10 \\
\text { Cochrane Score } \\
5 / 10\end{array}$ & $\begin{array}{l}44 \text { patients with low } \\
\text { back and leg pain }\end{array}$ & $\begin{array}{l}\text { Caudal epidural vs lumbar } \\
\text { epidural. }\end{array}$ & Visual Analog Scale & $\begin{array}{l}\text { There was no significant } \\
\text { improvement. There were } \\
\text { no differences between } \\
\text { both techniques }\end{array}$ & $\begin{array}{l}\text { Negative short term } \\
\text { and long term relief. }\end{array}$ \\
\hline $\begin{array}{l}\text { Breivik et al (142) } \\
\text { Randomized } \\
\text { double blind trial. } \\
\text { Randomization } \\
\text { according to a list of } \\
\text { random numbers. } \\
\text { Parallel, cohort design } \\
\text { AHRQ Score } \\
8 / 10 \\
\text { Cochrane Score } \\
7 / 10\end{array}$ & $\begin{array}{l}35 \text { patients with } \\
\text { incapacitating chronic } \\
\text { low back pain and } \\
\text { sciatica. } \\
\text { Diagnosis based } \\
\text { on radiculopathy: } \\
\text { arachnoiditis }(\mathrm{n}=8) \text {, no } \\
\text { abnormality }(\mathrm{n}=11) \text {, } \\
\text { inconclusive findings } \\
(\mathrm{n}=5) \text {. } \\
\text { Duration:several months } \\
\text { to several years. }\end{array}$ & $\begin{array}{l}\text { Caudal epidural injection: } \\
\text { Experimental: } 20 \mathrm{~mL} \\
\text { bupivacaine } 0.25 \% \text { with } 80 \mathrm{mg} \\
\text { depomethylprednisone }(\mathrm{n}=16) \\
\text { Placebo: } 20 \mathrm{~mL} \text { bupivacaine } \\
0.25 \% \text { followed by } 100 \mathrm{~mL} \\
\text { saline ( } \mathrm{n}=19) \text {. } \\
\text { Frequency: up to three } \\
\text { injections at weekly intervals. }\end{array}$ & $\begin{array}{l}\text { Timing: not mentioned. } \\
\text { Outcome measures: } \\
\text { 1. Pain relief: } \\
\text { significant diminution } \\
\text { of pain and/or paresis } \\
\text { to a degree that enabled } \\
\text { return to work } \\
\text { 2. Objective } \\
\text { improvement: } \\
\text { sensation, Lasègue's } \\
\text { test, paresis, spinal } \\
\text { reflexes, and sphincter } \\
\text { disorders }\end{array}$ & $\begin{array}{l}56 \% \text { of the patients reported } \\
\text { considerable pain relief } \\
\text { in experimental group } \\
\text { compared to } 26 \% \text { of the } \\
\text { patients in the placebo group. }\end{array}$ & $\begin{array}{l}\text { Positive short-term } \\
\text { and long-term }\end{array}$ \\
\hline $\begin{array}{l}\text { Bush and Hillier (143) } \\
\text { Randomized double } \\
\text { blind trial. } \\
28 \text { patients were } \\
\text { randomized; only } 23 \\
\text { patients were entered } \\
\text { into the study. } \\
\text { AHRQ Score- } 8 / 10 \\
\text { Cochrane Score } \\
8 / 10\end{array}$ & $\begin{array}{l}23 \text { patients with lumbar } \\
\text { nerve root compromise. } \\
\text { Mean duration (range) } \\
\text { in experimental group: } \\
5.8 \text { months (1-13 } \\
\text { months) and in control } \\
\text { group } 4.7 \text { months (1-12). }\end{array}$ & $\begin{array}{l}\text { Caudal epidural injections: } \\
\text { Experimental: } 25 \mathrm{~mL}: \\
80 \mathrm{mg} \text { triamcinolone acetonide } \\
+0.5 \% \text { procaine hydrochloride } \\
(\mathrm{n}=12) \\
\text { Control: } 25 \mathrm{~mL} \text { normal saline } \\
\text { ( } \mathrm{n}=11) \\
\text { Frequency: two caudal } \\
\text { injections, the first after } \\
\text { admission to the trial and a } \\
\text { second after } 2 \text { weeks }\end{array}$ & $\begin{array}{l}\text { Timing: four weeks and } \\
\text { at one year. } \\
\text { Outcome measures: } \\
\text { 1. Effect on lifestyle } \\
\text { 2. Back and leg pain } \\
\text { 3. Angle of positive SLR }\end{array}$ & $\begin{array}{l}\text { Significantly better results } \\
\text { with pain and straight leg } \\
\text { raising in experimental group } \\
\text { in short-term. } \\
\text { Pain not significantly } \\
\text { different but straight leg raise } \\
\text { significantly better for long- } \\
\text { term relief. }\end{array}$ & $\begin{array}{l}\text { Positive short-term } \\
\text { and negative long- } \\
\text { term }\end{array}$ \\
\hline $\begin{array}{l}\text { Matthews et al (144) } \\
\text { Double blind. } \\
\text { Stratification by age } \\
\text { and gender. } \\
\text { Survival curve } \\
\text { analyses based on } \\
\text { cumulative totals } \\
\text { recovered. } \\
\text { AHRQ Score - } 8 / 10 \\
\text { Cochrane Score } \\
7 / 10\end{array}$ & $\begin{array}{l}57 \text { patients with sciatica } \\
\text { with a single root } \\
\text { compression } \\
\text { Experimental group: } \\
\text { male/female: } 19 / 4 \text {, } \\
\text { median duration of pain: } \\
4 \text { weeks . } \\
\text { Control group: male/ } \\
\text { female: } 24 / 10 \text {, median } \\
\text { duration of pain: } 4 \\
\text { weeks. }\end{array}$ & $\begin{array}{l}\text { Caudal epidural injections: } \\
\text { Experimental: } 20 \mathrm{~mL} \\
\text { bupivacaine } 0.125 \%+2 \mathrm{~mL}(80 \\
\mathrm{mg}) \text { methylprednisolone acetate } \\
(\mathrm{n}=23) \text {. } \\
\text { Control: } 2 \text { mL lignocaine (over } \\
\text { the sacral hiatus or into a tender } \\
\text { spot) }(\mathrm{n}=34) \\
\text { Frequency: fortnightly intervals, } \\
\text { up to three times as needed }\end{array}$ & $\begin{array}{l}\text { Timing: } 2 \text { weeks, } 1,3,6 \text {, } \\
\text { and } 12 \text { months. } \\
\text { Outcome measures: } \\
\text { 1. Pain (recovered } v s \\
\text { not recovered) } \\
\text { 2. Range of movement } \\
\text { 3. Straight leg raising } \\
\text { 4. Neurologic } \\
\text { examination }\end{array}$ & $\begin{array}{l}\text { There was no significant } \\
\text { difference between } \\
\text { experimental and control } \\
\text { group with short-term relief } \\
\text { ( } 67 \% \text { vs } 56 \%) \text {. } \\
\text { After } 3 \text { months, patients in } \\
\text { experimental group reported } \\
\text { significantly more pain-free } \\
\text { than in control group. }\end{array}$ & $\begin{array}{l}\text { Negative short-term } \\
\text { and positive long- } \\
\text { term }\end{array}$ \\
\hline $\begin{array}{l}\text { Helsa and Breivik } \\
(147) \\
\text { Double blind trial } \\
\text { with crossover design } \\
\text { AHRQ Score - 7/10 } \\
\text { Cochrane Score } \\
7 / 10\end{array}$ & $\begin{array}{l}69 \text { patients with } \\
\text { incapacitating chronic } \\
\text { low back pain and } \\
\text { sciatica. } \\
36 \text { of } 69 \text { previously } \\
\text { been operated on for } \\
\text { herniated disc. }\end{array}$ & $\begin{array}{l}\text { Three caudal epidural injections } \\
\text { of either bupivacaine with } \\
\text { depomethylprednisolone } \\
80 \text { mg or with bupivacaine } \\
\text { followed by normal saline. If } \\
\text { no improvement had occu-rred } \\
\text { after } 3 \text { injections, a series of } \\
\text { the alternative type of injection } \\
\text { was given. }\end{array}$ & $\begin{array}{l}\text { Timing: not mentioned. } \\
\text { Outcome measures: } \\
\text { significant } \\
\text { improvement to } \\
\text { return to work or to be } \\
\text { retrained for another } \\
\text { occupation. }\end{array}$ & $\begin{array}{l}\text { i. } 34 \text { of the } 58 \text { patients ( } 59 \%) \\
\text { receiving caudal epidural } \\
\text { injections of bupivacaine } \\
\text { and depomethylprednisolone } \\
\text { showed significant } \\
\text { improvement. } \\
\text { ii. } 12 \text { of } 49 \text { patients ( } 25 \%) \\
\text { who received bupivacaine } \\
\text { followed by saline were } \\
\text { improved. }\end{array}$ & $\begin{array}{l}\text { Positive short-term } \\
\text { and long-term }\end{array}$ \\
\hline $\begin{array}{l}\text { Revel et al (148) } \\
\text { Randomized trial. } \\
\text { AHRQ Score } \\
7 / 10 \\
\text { Cochrane Score } \\
6 / 10\end{array}$ & $\begin{array}{l}60 \text { post lumbar } \\
\text { laminectomy patients } \\
\text { with chronic low back } \\
\text { pain. }\end{array}$ & $\begin{array}{l}\text { Forceful caudal injection: } \\
\text { Experimental: } 125 \mathrm{mg} \text { of pred- } \\
\text { nisolone acetate with } 40 \mathrm{~mL} \text { of } \\
\text { normal saline in the treatment } \\
\text { group. } \\
\text { Control: } 125 \mathrm{mg} \text { of predni-so- } \\
\text { lone in the control group. }\end{array}$ & $\begin{array}{l}\text { Timing: } 6 \text { months. } \\
\text { Outcome measures: } \\
\text { pain relief }\end{array}$ & $\begin{array}{l}\text { The proportion of patients } \\
\text { relieved of sciatica was } 49 \% \\
\text { in the forceful injection } \\
\text { group compared to } 19 \% \\
\text { in the control group with } \\
\text { significant difference. }\end{array}$ & $\begin{array}{l}\text { Positive short-term } \\
\text { and negative long- } \\
\text { term }\end{array}$ \\
\hline $\begin{array}{l}\text { Meadeb et al (149) } \\
\text { Randomized trial. } \\
\text { Parallel-group study. } \\
\text { AHRQ Score } \\
6 / 10 \\
\text { Cochrane Score } \\
6 / 10\end{array}$ & $\begin{array}{l}47 \text { post lumbar } \\
\text { laminectomy syndrome } \\
\text { patients in a multicenter } \\
\text { study. }\end{array}$ & $\begin{array}{l}\text { Experimental : forceful injec- } \\
\text { tion of } 20 \mathrm{~mL} \text { of normal saline } \\
\text { with/without } 125 \mathrm{mg} \text { of epidu- } \\
\text { ral prednisolone acetate. Con- } \\
\text { trol: } 125 \mathrm{mg} \text { of epidural pred- } \\
\text { nisolone. } \\
\text { Frequency: each of the } 3 \text { treat- } \\
\text { ments were provided once } \\
\text { a month for } 3 \text { consecutive } \\
\text { months. }\end{array}$ & $\begin{array}{l}\text { Timing: day 1, day } 30 \\
\text { and day } 120 . \\
\text { Outcome measures: } \\
\text { Visual Analog Scale }\end{array}$ & $\begin{array}{l}\text { The VAS scores improved } \\
\text { steadily in the forceful } \\
\text { injection group, producing a } \\
\text { nonsignificant difference on } \\
\text { day } 120 \text { as compared to the } \\
\text { baseline (day } 30=120 \text { days). }\end{array}$ & $\begin{array}{l}\text { Negative short-term } \\
\text { and long-term }\end{array}$ \\
\hline
\end{tabular}


Table 7. Characteristics and results of prospective studies of caudal epidural injections

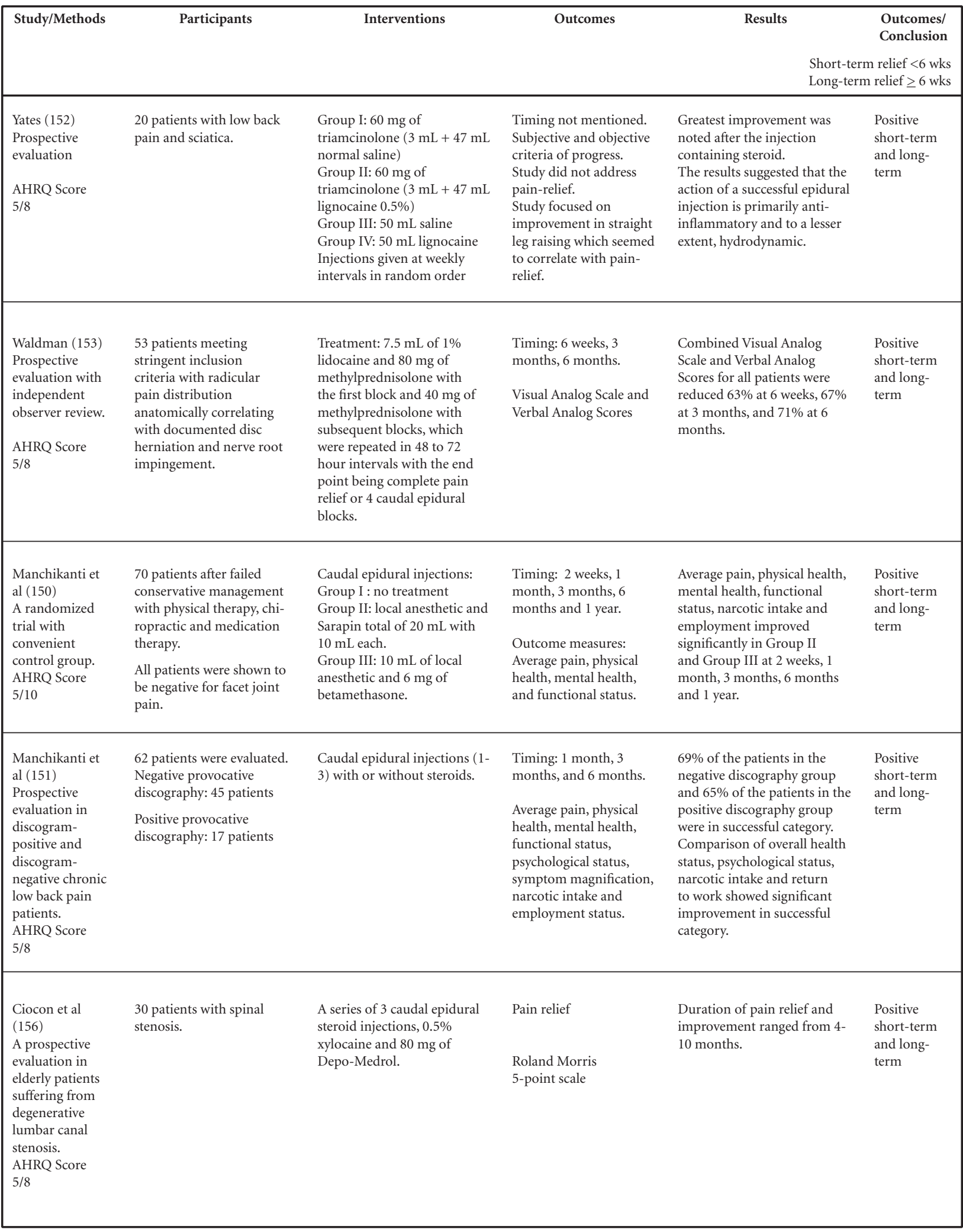


laminectomy syndrome. The evidence is moderate in managing chronic low back pain for short-term and long-term improvement.

\section{Complications}

Our search strategy yielded a total of 287 results. The most common and worrisome complications of caudal, interlaminar, and transforaminal epidural injections are of two types: those related to the needle placement and those related to drug administration. Complications include dural puncture, spinal cord trauma, infection, hematoma formation, abscess formation, subdural injection, intracranial air injection, epidural lipomatosis, pneumothorax, nerve damage, headache, death, brain damage, increased intracranial pressure, intravascular injection, vascular injury, cerebral vascular or pulmonary embolus and effects of steroids (21, 157-217). Spinal cord trauma, and spinal cord or epidural hematoma formation is a catastrophic complication that is rarely seen following interventional procedures in the cervical spine, thoracic spine or upper lumbar spine.

Houten and Errico (187) reported 3 cases of paraplegia after lumbosacral nerve root block in post laminectomy patients. They reported that in each case (performed at three different facilities, in the hands of two different physicians), the needle placement was verified with injection of contrast in conjunction with computerized tomography or biplanar fluoroscopy. In each patient, paraplegia was reported suddenly after injection of a steroid solution, and in each instance, post procedure magnetic resonance imaging revealed spinal cord edema in the low thoracic region. The authors postulated that in these patients, the spinal needle penetrated or injured an abnormally low dominant radiculomedullary artery, a recognized anatomical variant. This vessel, also known as the artery of Adamkiewicz, in $85 \%$ of individuals arises between $\mathrm{T} 9$ and L2, usually from the left, but in a minority of people, may arise from the lower lumbar spine and rarely even from as low as S1 (187). This artery travels with the nerve root through the neural foramen, supplying the anterior spinal cord (187). Injury of the artery or injection of particulate steroid may result in infarction of the lower thoracic spinal cord.

Cousins (205) described a potential complication related to inadvertent in- travascular administration of particulate depo-corticosteroids producing occlusion of small end arteries, which resulted in visual defects in one case, and hearing loss in another case, after a suboccipital nerve block. It is felt that methylprednisolone acetate tends to form aggregates of steroid material when mixed with local anesthetic and may pose more of a risk for this problem than other depo-steroids.

Brouwers et al (189) reported a cervical anterior spinal artery syndrome after diagnostic blockade of right C6 nerve root with fatal cervical spinal cord infarction. Nash (190) reported that he was aware of 3 cases with persistent neurological deficit following root sleeve injections of cervical and lumbar regions. Other transforaminal disasters have been described $(183,184,197)$.

Side effects related to the administration of steroids are generally attributed either to the chemistry or to the pharmacology of the steroids. The major theoretical complications of corticosteroid administration include suppression of pituitaryadrenal axis, hypercorticism, Cushing's syndrome, osteoporosis, avascular necrosis of bone, steroid myopathy, epidural lipomatosis, weight gain, fluid retention, and hyperglycemia. The most commonly used steroids in neural blockade in the United States, methylprednisolone acetate, triamcinolone acetonide, and betamethasone acetate and phosphate mixture have all been shown to be safe at epidural therapeutic doses in both clinical and experimental studies (207-216).

\section{DISCUSSION}

This systematic review evaluated the effectiveness of epidural injections in patients with chronic spinal pain. The evidence was evaluated for 3 types of epidurals separately for cervical and lumbar, and for axial, radicular and post laminectomy pain.

This systematic review arrived at the following conclusions. In managing lumbar radicular pain with interlaminar lumbar epidural steroid injections, the level of evidence is strong for short-term relief and limited for long-term relief. In managing cervical radiculopathy with cervical interlaminar epidural steroid injections, the evidence is moderate for short-term improvement and long-term improvement. However, the evidence is inconclusive in management of axial neck pain, ax- ial low back pain, and lumbar spinal stenosis with lumbar or cervical interlaminar epidural steroid injections.

The evidence for lumbar transforaminal epidural steroid injections in managing lumbar nerve root pain is strong with short-term and long-term improvement. The evidence for cervical transforaminal epidural steroid injections in managing cervical nerve root pain, is strong with short-term and long-term improvement. The evidence is moderate in managing lumbar radicular pain in post lumbar laminectomy syndrome, with shortterm and long-term improvement. The evidence of lumbar transforaminal epidural steroid injections in managing lumbar spinal stenosis is limited. The evidence is indeterminate in managing axial low back pain, axial neck pain, and lumbar disc extrusions.

The evidence of caudal epidural steroid injections with randomized trials and non-randomized reports is strong for short-term relief and moderate for longterm relief, in managing chronic pain of lumbar radiculopathy and post lumbar laminectomy syndrome. The evidence is moderate in managing chronic low back pain for short-term and long-term improvement. The evidence is limited for lumbar spinal stenosis.

The first systematic review of effectiveness of epidural steroid injections was performed by Kepes and Duncalf in 1985 (40). They concluded that the rationale for epidural and systemic steroids was not proven. However, in 1986 Benzon (42), utilizing the same studies, concluded that mechanical causes of low back pain, especially those accompanied by signs of nerve root irritation, may respond to epidural steroid injections. The difference in the conclusion of Kepes and Duncalf (40) and Benzon (42) may have been due to the fact that Kepes and Duncalf (40) included studies on systemic steroids whereas Benzon (41) limited his analysis to studies on epidural steroid injections only.

The debate concerning epidural steroid injections is also illustrated by the recommendations of the Australian National Health and Medical Research Council Advisory Committee on epidural steroid injections (21). In this report, Bogduk et al (21) extensively studied caudal, interlaminar, and transforaminal epidural injections, including all the literature available at the time, and concluded 
that the balance of the published evidence supports the therapeutic use of caudal epidurals. They also concluded that the results of lumbar interlaminar epidural steroids strongly refute the utility of epidural steroids in acute sciatica. Bogduk (42) updated his recommendations in 1999 , recommending against epidural steroids by the lumbar route because effective treatment required too high a number for successful treatment, but supporting the potential usefulness of transforaminal steroids for disc prolapse. In 1995, Koes et al (43) reviewed 12 trials of lumbar and caudal epidural steroid injections and reported positive results from only six studies. However, review of their analysis showed that there were 5 studies for caudal epidural steroid injections and 7 studies for lumbar epidural steroid injections. Four of the five studies involving caudal epidural steroid injections were positive, whereas 5 of 7 studies were negative for lumbar epidural steroid injections. Koes et al (44) updated their review of epidural steroid injections for low back pain and sciatica, including three more studies with a total of 15 trials which met the inclusion criteria. In this study, they concluded that of the 15 trials, eight reported positive results of epidural steroid injections. Both reviews mostly reflected the quality of studies, rather than any meaningful conclusion.

Nelemans et al's (45) Cochrane review of injection therapy for subacute and chronic benign low back pain included 21 randomized trials. Of these, 9 were of epidural steroids. They failed to separate caudal from interlaminar epidural injections, but still concluded that convincing evidence is lacking regarding the effects of injection therapy on low back pain. Rozenberg et al (46), in a systematic review, identified 13 trials of epidural steroid therapy. They concluded that 5 trials demonstrated greater pain relief within the first month in the steroid group as compared to the control group. Eight trials found no measurable benefits. They noticed many obstacles for meaningful comparison of cross studies, which included differences in the patient populations, steroid used, volume injected, and number of injections. These authors were unable to determine whether epidural steroids are effective in common low back pain and sciatica based on their review. Rozenburg et al (46) concluded that
3 of the top 5 rated studies did not demonstrate significant benefit of the steroid over the non-steroid group. Hopayiank and Mugford (47) expressed frustration over the conflicting conclusions from two systematic reviews of epidural steroid injections for sciatica and asked which evidence should general practitioners heed? Multiple previous reviews have criticized the studies evaluating the effectiveness of epidural injections. Criticisms ranged from methodology, small size of the study populations, and other limitations, including long-term follow-up and outcome parameters. Many of these deficiencies were noted in our review also, in spite of the fact that we have included non-randomized trials.

The present systematic review is different from all the previous systematic reviews. The present systematic review has several additional features: epidural steroid injections involving cervical and lumbar regions were evaluated; radicular pain, axial pain, post lumbar laminectomy pain, and pain due to spinal stenosis; randomized and observational studies were taken into consideration; the review was performed by physicians who performed these procedures routinely, although none of the reviewed studies were conducted by these physicians. Consequently, we have reached different conclusions than the previous studies.

Finally, all types of epidural steroid injections can be associated with complications and adverse events as described earlier. Therefore attention to detail and caution should be taken when performing any of the three techniques discussed in order to improve safety and minimize complications.

\section{Conclusion}

This systematic review, which included not only randomized trials, but also all available non-randomized trials, showed variable effectiveness of epidural injections.

The evidence ranged from indeterminate to strong based on the condition involved, the region involved, and pathology. It is crucial to understand the available evidence so that evidence based medical approach can be used when selecting these interventional procedures for our patients.
Appendix A. AHRQ's key domains (appearing in intalics) or systems to rate quality of randomized controlled studies (48).

Study Question

Study Population

Randomization

Blinding

Interventions

Outcomes

Statistical Analysis

Results

Discussion

Funding or Sponsorship

Appendix B. $A H R Q$ 's key elements for systems to rate quality of randomized controlled trials (48).

Elements appearing in italics are those with an empirical basis. Elements appearing in bold are those considered essential to give a system a Yes rating for the domain. For purposes of this systematic review, the bold elements were considered, and to be included studies needed to have at least 5 of the 10 essential elements.

- Specific inclusion and exclusion criteria

- Adequate approach to sequence generation

- Adequate concealment method used

- Similarity of groups at baseline

- Double-blinding (e.g., of investigators, caregivers, subjects, assessors, and other key study personnel as appropriate) to treatment allocation

- Intervention(s) clearly detailed for all study groups (e.g., dose, route, timing for drugs, and details sufficient for assessment and reproducibility for other types of interventions)

- Primary and secondary outcome measures specified

- Appropriate analytic techniques that address study withdrawals, loss to follow$u p$, missing data, and intention to treat

- Measure of effect for outcomes and appropriate measure of precision

- Conclusions supported by results with possible biases and limitations taken into consideration

- Type and sources of support for study

Appendix C. AHRQ's key domains or systems to rate quality of observational studies (48).

$\dagger$ Domain for which a Yes rating required that a majority of elements be considered.

Study Question

Study Population

Comparability of Subjects $\dagger$

Exposure or Intervention 
Outcome Measurement

Statistical Analysis

Results

Discussion

Funding or Sponsorship

Appendix D. AHRQ's key elements for systems to rate quality of observational studies (48).

${ }^{\star}$ Elements appearing in italics are those with an empirical basis. Elements appearing in bold are those considered essential to give a system a Yes rating for the domain. For purposes of this systematic review, the bold elements were considered, and to be included studies needed to have at least 5 of the 8 essential elements.

- Clearly focused and appropriate question

- Description of study populations

- Use of concurrent controls

- Clear definition of exposure

- Primary/secondary outcomes clearly defined

- Assessment of confounding factors

- Measure of effect for outcomes and appropriate measure of precision

- Conclusions supported by results with possible biases and limitations taken into consideration

- Type and sources of support for study

Appendix E. Methodologic quality criteria list (key items of internal validity) of Cochrane Musculoskeletal Review Group (49).

Patient selection
1. Treatment allocation
Was the method of randomization described and adequate?
Was the treatment allocation concealed?
2. Were the groups similar at baseline regarding the most important prognostic indicators?

\section{Intervention}

3. Was the care provider blinded?

4. Was controlled for co-interventions which could explain the results?

5. Was the compliance rate (in each group) unlikely to cause bias?

6.. Was the patient blinded?

Outcome measurement

7. Was the outcome assessor blinded?

8. Was at least one of the primary outcome measures applied?

9. Was the withdrawal/drop-out rate unlikely to cause bias?

Statistics

10. Did the analysis include an intention-to-treat analysis?
Appendix F. Inclusion/exclusion

criteria (50).

1. Are the patients described in sufficient detail to allow you to decide whether they are comparable to those that are seen in clinical practices of interventional pain management?

A) Setting - office, hospital, outpatient, inpatient

B) Physician - interventional pain physician, general physician, anesthesiologist, physiatrist, neurologist, rheumatologist, orthopedic surgeon, neurosurgeon, etc.

C) Patient characteristics - duration of pain

D) Non-interventional techniques or surgical intervention in the past

E) Exclusion criteria

F) Inclusion criteria

2. Is the intervention described well enough to enable you to provide the same for patients in interventional pain management settings?

A) Nature of intervention

B) Frequency of intervention

C) Duration of intervention

3. Were clinically relevant outcomes measured?

A) Proportion of pain relief

B) Disorder/specific disability

C) Functional improvement

D) Allocation of eligible and non-eligible patients to return to work

E) Ability to work

F)Psychological assessment or improvement

\section{Author Affiliation}

Salahadin Abdi, MD, PhD

Director, Massachusetts General

Hospital, Pain Center

15 Parkman Street, Suite 333B

Boston MA 02114

Harvard Medical School

Boston, Massachusetts, 02114

E-Mail: sabdi@partners.org

\section{Sukdeb Datta, MD}

Director, Pain Management Center VA Tennessee Valley Healthcare System $131024^{\text {th }}$ Avenue South

Nashville, TN 37212

sukdeb@hotmail.com

Linda F. Lucas, MD

Associate Professor

Department of Anesthesiology and

Perioperative Medicine

Director of Pain Management

Fellowship

University of Louisville School of

Medicine

530 S. Jackson Street

Louisville, Kentucky 40202

E-Mail:1fluca01@louisville.edu

\section{REFERENCES}

1. Manchikanti L, Staats PS, Singh V, Schultz DM, Vilims BD, Jasper JF, Kloth DS, Trescot AM, Hansen HC, Falasca TD, Racz GB, Deer T, Burton AW, Helm S, Lou L, Bakhit CE, Dunbar EE, Atluri SL, Calodney AK, Hassenbusch S, Feler CA. Evidence-based practice guidelines for interventional techniques in the management of chronic spinal pain. Pain Physician 2003; 6:3-80.

2. Lawrence RC, Helmick CG, Arnett FC. Estimates of the prevalence of arthritis and selected musculoskeletal disorders in the United States. Arthritis Rheum 1998; 41: 778-799.

3. Bressler HB, Keyes WJ, Rochon PA, Badley $\mathrm{E}$. The prevalence of low back pain in the elderly. A systemic review of the literature. Spine 1999; 24:1813-1819.

4. Cassidy D, Carroll L, Cotê P: The Saskatchewan Health and Back Pain Survey. The prevalence of low back pain and related disability in Saskatchewan Adults. Spine 1998; 23:1860-1867.

5. Côté DC, Cassidy JD, Carroll L. The Saskatchewan Health and Back Pain Survey. The prevalence of neck pain and related disability in Saskatchewan adults. Spine 1998; 23:1689-1698.

6. Yeung SS, Genaidy A, Deddens J, Alhemood A, Leung PC. Prevalence of musculoskeletal symptoms in single and multiple body regions and effects of perceived risk of injury among manual handling workers. Spine 2002; 27:2166-2172.

7. Bell G, Kidd D, North R. Cost-effectiveness analysis of spinal cord stimulation in treatment of failed back surgery syndrome. J Pain Symp Manage 1997; 13:286-295.

8. Evans TH, Mayer TG, Gatchel RJ. Recurrent disabling work-related spinal disorders after prior injury claims in a chronic low back pain population. The Spine Journal 2001; 1:183-189.

9. Enthoven P, Skargren E, Oberg B. Clinical course in patients seeking primary care for back or neck pain: A prospective 5-year follow-up of outcome and health care consumption with subgroup analysis. Spine 2004; 29:2458-2465.

10. Sjolie AN. Persistence and change in nonspecific low back pain among adolescents: a 3-year prospective study. Spine 2004; 29:2452-2457.

11. Brattberg G. Do pain problems in young school children persist into early adulthood? A 13-year follow-up. Eur J Pain 2004; 8:187-99.

12. Elders LA, Burdorf A. Prevalence, incidence, and recurrence of low back pain in scaffolders during a 3-year follow-up study. Spine 2004; 29:E101-E106.

13. Smith BH, Elliott AM, Hannaford PC, Chambers WA, Smith WC. Factors related to the onset and persistence of chronic back pain in the community: results from a general population follow-up study. Spine 2004; 29:1032-1040. 
14. Daffner SD, Hilibrand AS, Hanscom BS, Brislin BT, Vaccaro AR, Albert TJ. Impact of neck and arm pain on overall health status. Spine 2003; 28:2030-2035.

15. Luo X, Pietrobon R, Sun SX, Liu GG, Hey L. Estimates and patterns of direct health care expenditures among individuals with back pain in the United States. Spine 2004; 29:79-86.

16. Turk DC. Clinical effectiveness and costeffectiveness of treatments for patients with chronic pain. Clin J Pain 2002; 18: 355-365.

17. Leigh JP, Markowitz SB, Fahs M, Shin C, Landrigan PJ. Occupational injury and illness in the United States. Estimates of costs, morbidity, and mortality. Arch Intern Med 1997; 157:1557-1568.

18. de Lissovoy G, Brown RE, Halpern M, Hassenbusch SJ, Ross E. Cost-effectiveness of long-term intrathecal morphine therapy for pain associated with failed back surgery syndrome. Clin Ther 1997; 19:96-112.

19. Manchikanti L. The growth of interventional pain management in the new millennium: A critical analysis of utilization in the Medicare population. Pain Physician 2004; 7:465-482.

20. Manchikanti L, Singh V, Kloth DS, Slipman CW, Jasper JF, Trescot AM, Varley KG, Atluri SL, Giron C, Curran MJ, Rivera JJ, Baha A, Bakhit CE, Reuter M. Interventional techniques in the management of chronic pain: Part 2.0. Pain Physician 2001; 4:24-96.

21. Bogduk N, Christophidis N, Cherry D. Epidural use of steroids in the management of back pain. Report of working party on epidural use of steroids in the management of back pain. National Health and Medical Research Council. Canberra, Commonwealth of Australia, 1994, pp 176.

22 Manchikanti L, Pakanati RR, Pampati V. Comparison of three routes of epidural steroid injections in low back pain. Pain Digest 1999; 9:277-285.

23 Boswell M, Hansen $\mathrm{H}$, Trescot $\mathrm{A}$, Hirsch J. Epidural steroids in the management of chronic spinal pain and radiculopathy. Pain Physician 2003; 6:319-334.

24. Byrod G, Otani K, Brisby H, Rydevik B, Olmarker K. Methylprednisolone reduces the early vascular permeability increase in spinal nerve roots induced by epidural nucleus pulposus application. J Orthop Res 2000; 18:983-987.

25. Fowler RJ, Blackwell GJ. Anti-inflammatory steroid induced biosynthesis of a phospholipase A2 inhibitor which prevents prostaglandin generation. Nature 1979; 278:456-459.

26. Devor M, Govrin-Lippmann R, Raber P. Corticosteroids suppress ectopic neural discharges originating in experimental neuromas. Pain 1985; 22:127-137.

27. Johansson A, Hao J, Sjolund B. Local corticosteroid application blocks transmission in normal nociceptor C-fibers. Acta Anaesthesiol Scand 1990; 34:335-338.
28. Olmarker K, Byrod G, Cornefjord M, Nordborg C, Rydevik B. Effects of methylprednisolone on nucleus pulposus-induced nerve root injury. Spine 1994; 19:18031808.

29. Hua SY, Chen YZ. Membrane receptor-mediated electrophysiological effects of glucocorticoid on mammalian neurons. Endocrinology 1989; 124:687-691.

30. Hayashi N, Weinstein JN, Meller ST, Lee HM, Spratt KF, Gebhart GF. The effect of epidural injection of betamethasone or bupivacaine in a rat model of lumbar radiculopathy. Spine 1998; 23:877-885.

31. Lee HM, Weinstein JN, Meller ST, Hayashi N, Spratt KF, Gebhart GF. The role of steroids and their effects on phospholipase A2. An animal model of radiculopathy. Spine 1998; 23:1191-1196.

32. Minamide A, Tamaki T, Hashizume H, Yoshida M, Kawakami M, Hayashi N. Effects of steroids and lipopolysaccharide on spontaneous resorption of herniated intervertebral discs. An experience study in the rabbit. Spine 1998; 23:870-876.

33. Kingery WS, Castellote JM, Maze M. Methylprednisolone prevents the development of autotomy and neuropathic edema in rats, but has no effect on nociceptive thresholds. Pain 1999; 80:555-566.

34. Johansson A, Bennett GJ. Effect of local methylprednisolone on pain in a nerve injury model. A pilot study. Reg Anesth 1997; 22:59-65.

35. Merskey H, Thompson EN. Nerve blocks and cognitive therapy: A beneficial failure. Pain Res Manage 2002; 7:175-176.

36. Li YM, Wingrove DE, Too HP, Marnerakis M, Stimson ER, Strichartz GR, Maggio JE. Local anesthetics inhibit substance $P$ binding and evoked increases in intracellular Ca2+. Anesthesiology 1995:82:166-173.

37. Fink BR, Cairns AM. Differential use-dependent (frequency-dependent) effects in single mammalian axons: Data and clinical considerations. Anesthesiology 1987; 67: 477-484.

38. Bogduk N, Govind J (eds). Epidural steroids. In Medical Management of Acute Lumbar Radicular Pain. 1st ed. University of Newcastle, Newcastle Bone and Joint Institute, Australia, 1999, pp 71-80.

39. Bogduk N (ed). Steroid injections. In Medical Management of Acute Cervical Radicular Pain. 1st ed. University of Newcastle, Newcastle Bone and Joint Institute, Australia, 1999, pp 85-90.

40. Kepes ER, Duncalf D. Treatment of backache with spinal injections of local anesthetics, spinal and systemic steroids. Pain 1985; 22:33-47.

41. Benzon HT. Epidural steroid injections for low back pain and lumbosacral radiculography. Pain 1986; 24:277.

42. Bogduk N. Epidural steroids for low back pain and sciatica. Pain Digest 1999; 9:226227.

43. Koes BW, Scholten RJ, Mens JM, Bouter LM. Efficacy of epidural steroid injections for low back pain and sciatica: A systematic review of randomized clinical trials. Pain 1995; 63:279-288.

44. Koes BW, Scholten RJ, Mens JMA, Bouter LM. Epidural steroid injections for low back pain and sciatica. An updated systematic review of randomized clinical trials. Pain Digest 1999; 9:241-247.

45. Nelemans PJ, deBie RA, deVet HC, Sturmans F. Injection therapy for subacute and chronic benign low back pain. Spine 2001; 26:501-515.

46. Rozenberg S, Dubourg G, Khalifa P, Paolozzi L, Maheu E, Ravaud P. Efficacy of epidural steroids in low back pain and sciatica: A critical appraisal by a French task force of randomized trials. Revue du Rhumatisme 1999; 66:79-85.

47. Hopayiank K, Mugford M. Conflicting conclusions from two systematic reviews of epidural steroid injections for sciatica: Which evidence should general practitioners heed? Br J Gen Pract 1999; 49:57-60.

48. West S, King V, Carey T, Lohr K, McKoy $\mathrm{N}$, Sutton S, Lux L. Systems to rate the strength of scientific evidence. Evidence Report/Technology Assessment No. 47 University of North Carolina: Agency for Healthcare Research and Quality. AHRQ Publication No. 02-E016; April 2002.

49. van Tulder M, Assendelft W, Koes B, Bouter LM. Method guidelines for systematic reviews in the Cochrane Collaboration Back Review Group for Spinal Disorders. Spine. 1997; 22:2323-2330.

50. Shekelle PG, Andersson G, Bombardier C, Cherkin D, Deyo R, Keller R, Lee C, Liang M, Lipscomb B, Spratt K. A brief introduction to the critical reading of the clinical literature. Spine 1994;19(suppl):2028S-2031S.

51. Cuckler JM, Bernini PA, Wiesel SW, Booth RE Jr, Rothman RH, Pickens GT. The use of epidural steroid in the treatment of radicular pain. J Bone Joint Surg 1985; 67:63-66.

52. Dilke TF, Burry HC, Grahame R. Extradural corticosteroid injection in the management of lumbar nerve root compression. BrMed J 1973; 2:635-637.

53. Serrao JM, Marks RL, Morley SJ, Goodchild CS. Intrathecal midazolam for the treatment of chronic mechanical low back pain: A controlled comparison with epidural steroid in a pilot study. Pain 1992; 48:5-12.

54. Klenerman L, Greenwood R, Davenport HT, White DC, Peskett S. Lumbar epidural injections in the treatment of sciatica. $\mathrm{Br}$ J Rheumatol 1984; 23:35-38.

55. Rocco AG, Frank E, Kaul AF, Lipson SJ, Gallo JP. Epidural steroids, epidural morphine and epidural steroids combined with morphine in the treatment of post-laminectomy syndrome. Pain 1989; 36:297-303.

56. Ridley MG, Kingsley GH, Gibson T, Grahame R.. Outpatient lumbar epidural corticosteroid injection in the management of sciatica. Br J Rheumatol 1988; 27:295299.

57. Rogers P, Nash T, Schiller D and Norman J. Epidural steroids for sciatica. Pain Clinic 
1992; 5:67-72.

58. Castagnera L, Maurette P, Pointillart V, Vital JM, Erny P, Senegas J. Long-term results of cervical epidural steroid injection with and without morphine in chronic cervical radicular pain. Pain 1994; 58:239243.

59. Hernandez R, Lopez F. Assessment of pain intensity in patients with diabetic polyneuropathy treated with peridural $2 \%$ lidocaine methylprednisolone acetate vs peridural $2 \%$ lidocaine. Anestesia en Mexico 1999; 11:65-69.

6o. Kikuchi A, Kotani N, Sato T, Takamura K, Sakai I, Matsuki A. Comparative therapeutic evaluation of intrathecal versus epidural methylprednisolone for long-term analgesia in patients with intractable postherpetic neuralgia. Reg Anesth Pain Med 1999; 24:287-293.

61. Kraemer J, Ludwig J, Bickert U, Owczarek V, Traupe M. Lumbar epidural perineural injection: A new technique. Eur Spine J 1997; $6: 357-361$.

62. Helliwell M, Robertson JC, Ellia RM. Outpatient treatment of low back pain and sciatica by a single extradural corticosteroid injection. Br J Clin Pract 1985; 39:228-231.

63. Stav A, Ovadia L, Sternberg A, Kaadan M, Weksler N. Cervical epidural steroid injection for cervicobrachialgia. Acta Anaesthe siol Scand 1993; 37:562-566.

64. Buchner M, Zeifang F, Brocai DR, Schiltenwolf $M$. Epidural corticosteroid injection in the conservative management of sciatica. Clin Orth Rel Res 2000; 375:149-156.

65. Carette S, Leclaire R, Marcoux S, Morin F, Blaise GA, St-Pierre A, Truchon R, Parent $F$, Levesque J, Bergeron V, Montminy P, Blanchette C. Epidural corticosteroid injections for sciatica due to herniated nucleus pulposus. N Engl J Med 1997; 336: 1634-1640.

66. Snoek W, Weber H, Jorgensen B. Doubleblind evaluation of extradural methylprednisolone for herniated lumbar disc. Acta Orthop Scand 1977; 48:635-641.

67. Valat JP, Giraudeau B, Rozenberg S, Goupille P, Bourgeois P, Micheau-Beaugendre V, Soubrier M, Richard S, Thomas E. Epidural corticosteroid injections for sciatica: a randomised, double blind, controlled clinical trial. Ann Rheum Dis 2003 62:639-43.

68. Pirbudak L, Karakurum G Oner U, Gulec A, Karadasli H. Epidural corticosteroid injection and amitriptyline for the treatment of chronic low back pain associated with radiculopathy. Pain Clinic 2003; 15:247253.

69. McGregor AH, Anjarwalla NK, Stambach T. Does the method of injection alter the outcome of epidural injections? J Spinal Dis ord 2001; 14:507-510.

70. Bush K, Hillier S. Outcome of cervical radiculopathy treated with periradicular/ epidural corticosteroid injections: A prospective study with independent clinical review. Eur Spine J 1996; 5:319-325.
71. Rull BM, Miralles M, Aure S. Therapeutic epidural infiltrations in the lumbar nerve roots. Revista de Ortopedia y Traumatologia 1996; 40:209-217.

72. Caglar S, Erdine S, Aldemir T. The results of the epidural steroid injections in patients with radiculopathies due to lumbar disc herniations. Fizik Tedavi Rehabilitasyon Dergisi 1995; 19:186-190.

73. Rivest C, Katz JN, Ferrante FM, Jamison RN. Effects of epidural steroid injection on pain due to lumbar spinal stenosis or herniated discs: A prospective study. Arthritis Care Res 1998; 11:291-297.

74 Koning HM; Koning AJ; Bruinen TCM; Koster HG; Heybroek E. The period of pain relief following a successful epidural steroid injection for low back pain. Pain Clinic 2002; 13:331-338.

75. Fukusaki M, Kobayashi I, Hara T, Sumikawa K. Symptoms of spinal stenosis do not improve after epidural steroid injection. Clin J Pain 1998; 14:148-151.

76. Andersen KH, Mosdal C. Epidural application of corticosteroids in low back pain and sciatica. Acta Neurochir 1987; 87:5253

77. Warfield CA, Crews DA. Epidural steroid injection as a predictor of surgical outcome. Surg Gyn Obstet 1987; 164:457458.

78. Stav A, Ovadia L, Landau M, Weksler N, Berman M. Epidural steroid injection in the treatment of lumbar and cervical pain syndromes. A preliminary retrospective comparison. Pain Clinic 1991; 4:95-112.

79. Shulman M. Treatment of neck pain with cervical epidural steroid injection. Reg Anesth 1986; 11:92-94.

8o. Catchlove RFH, Braha R. The use of cervical epidural nerve blocks in the management of chronic head and neck pain. Can Anaesth Soc J 1984; 31:188-191.

81. Berman AT, Garbarino JL Jr, Fisher SM, Bosacco SJ. The effects of epidural injection of local anesthetics and corticosteroids in patients with lumbosciatic pain. Clin Orthop 1984; 188:144-151.

82. Purkis IE. Cervical epidural steroids. Pain Clinic 1986; 1:3-7.

83. Rowlingson JC, Kirschenbaum LP. Epidural analgesic techniques in the management of cervical pain. Anesth Analg 1986; 65: 938-942.

84. Warfield CA, Biber MP, Crews DA, Dwarakanath,GK. Epidural steroid injection as a treatment for cervical radiculitis. Clin J Pain 1988; 4:201-204.

85. Cicala RS, Thoni K, Angel JJ. Long-term results of cervical epidural steroid injections. Clin J Pain 1989; 5:143-145.

86. Pawl RP, Anderson W, Shulman M. Effect of epidural steroids in the cervical and lumbar region on surgical intervention for discogenic spondylosis. Clin J Pain 1985; 1 : 181-185.

87. Ferrante FM, Wilson SP, Iacobo C, Orav EJ, Rocco AG, Lipson S. Clinical classification as a predictor of therapeutic outcome after cervical epidural steroid injection. Spine 1993; 18:730-736.

88. Klein GR, Vaccaro AR, Cwik J, Seitchik S, Viscusi ER, Albert TJ. Efficacy of cervical epidural steroids in the treatment of cervical spine disorders. Am J Anesthesiol 2000; 9:547-552.

89. Ozyalcin S, Yucel A, Erdine S. Epidural steroid injection in the treatment of cervical pain syndromes: A retrospective follow up study. Angri Dergisi 1996; 8:9-14.

90. Hickey RF. Outpatient epidural steroid in jections for low back pain and lumbosacral radiculopathy. NZ Med J 1987; 100:54-59.

91. Heyse-Moore GH. A rational approach to the use of epidural medication in the treatment of sciatic pain. Acta Orthop Scand 1978; 49:366-370.

92. Harley C. Extradural corticosteroid infiltration. A follow-up study of 50 cases. Ann Phy Med 1966; 9:22-28.

93. Sharma S, Stedman R. Epidural steroids. A retrospective analysis of the efficacy of high and low dose therapy. Anesthesiology 1998; 3A:A1135.

94. Rosen CD, Kahanovitz N, Bernstein R, Viola $K$. A retrospective analysis of the efficacy of epidural steroid injections. Clin Orthop 1988; 228:270-272.

95. Arnhoff FN, Triplett HB, Pokorney B. Follow-up status of patients treated with nerve blocks for low back pain. Anesthesiology 1977; 46:170-178.

96. Jamison RN, VadeBoncouer T, Ferrante FM. Low back pain patients unresponsive to an epidural steroid injection: Identifying predictive factors. Clin J Pain 1991; 7:311-317.

97. Hopwood MB, Abram SE. Factors associated with failure of lumbar epidural steroids. Reg Anesth 1993; 18:238-243.

98. Reale C, Turkiewicz AM, Reale CA, Stabile S, Borgonuovo P, Apponi F. Epidural steroids as a pharmacological approach. Clin Exp Rheumatol 2000; 18:S65-S66.

99. Bowman SJ, Wedderburn L, Whaley A, Grahame R, Newman S. Outcome assessment after epidural corticosteroid injection for low back pain and sciatica. Spine 1993; 18:1345-1350.

100. Jurmand $\mathrm{SH}$. Cortiotherapie peridurale des lombalgies et des sciatiques d'origine dis cale. Concours Medicale 1972; 94:50615070.

101. Ito R. The treatment of low back pain and sciatica with epidural corticosteroids injection and its pathophysiologic basis. J Jpn Orthop Assoc 1971; 45:769-777.

102. Brown FW. Management of discogenic pain using epidural and intrathecal steroids. Clin Orthop 1977; 129:72-78.

103. Warr AC, Wilkinson JA, Burn JM, Langdon L. Chronic lumbosciatica syndrome treated by epidural injection and manipulation. Practitioner 1977; 209:53-59.

104. Papagelopoulos PJ, Petrou HG, Triantafyllidis PG, Vlamis JA, Psomas-Pasalis M, Korres DS, Stamos KG. Treatment of lumbosa- 
cral radicular pain with epidural steroid injections. Orthopedics 2001; 24:145-149.

105. Silva J, Costa AO, Simoes MT, Neto RR. Management of radicular pain from lumbar herniated disc using betamethasone epidural injection. Revista Brasileira de Ortopedia 1999; 34:165-168.

106. Mangar D, Thomas PB. Epidural steroid injections in the treatment of cervical and lumbar pain syndromes. Reg Anesth 1991; 16:246.

107. Riew KD, Yin Y, Gilula L, Bridwell KH, Lenke LG, Lauryssen C, Goette K. The effect of nerve-root injections on the need for operative treatment of lumbar radicular pain. J Bone Joint Surg AM 2000; 82: 1589-1593.

108. Karppinen J, Malmivaara A, Kurunlahti M, Kyllonen E, Pienimaki T, Nieminen P, Ohinmaa A, Tervonen O, Vanharanta H. Periradicular infiltration for sciatica. Spine 2001; 26:1059-1067.

109. Karppinen J, Ohinmaa A, Malmivaara A, Kurunlahti M, Kyllonen E, Pienimaki T, Nieminen P, Tervonen O, Vanharanta $\mathrm{H}$. Cost effectiveness of periradicular infiltration for sciatica. Spine 2001; 26:2587-2595.

110. Devulder J, Deene P, De Laat M, Van Bastelaere M, Brusselmans G, Rolly G. Nerve root sleeve injections in patients with failed back surgery syndrome: A comparison of three solutions. Clin J Pain 1999; 15: 132-135.

111. Kolsi I, Delecrin J, Berthelot JM, Thomas L, Prost A, Maugars Y. Efficacy of nerve root versus interspinous injections of glucocorticoids in the treatment of disc-related sciatica. A pilot, prospective, randomized, double-blind study. Joint Bone Spine 2000; 67:113-118.

112. Vad VB, Bhat AL, Lutz GE, Cammisa F. Transforaminal epidural steroid injections in lumbosacral radiculopathy; A prospective randomized study. Spine 2002; 27:1116.

113. Thomas E, Cyteval C, Abiad L, Picot MC, Taourel P, Blotman F. Efficacy of transforaminal versus interspinous corticosteroid injection in discal radiculalgia - a prospective, randomised, double-blind study. Clin Rheumatol 2003; 22:299-304.

114. Lutz GE, Vad VB, Wisneski RJ. Fluoroscopic transforaminal lumbar epidural steroids: An outcome study. Arch Phys Med Rehabil 1998; 79:1362-1366.

115. Berger O, Dousset V, Delmer O, Pointillart V, Vital JM, Caille JM. Evaluation of the efficacy of foraminal infusions of corticosteroids guided by computed tomography in the treatment of radicular pain by foraminal injection. J Radiol 1999; 80:917-925.

116. Melzer A, Seibel RM. Magnetic resonance (MR)-guided percutaneous pain therapy of degenerative spinal diseases. Semin Interv Radiol 1999; 16:143-150.

117. Sequeiros RB, Ojala RO, Klemola R, Vaara TJ, Jyrkinen L, Tervonen OA. MRI-guided periradicular nerve root infiltration therapy in low-field (0.23-T) MRI system using optical instrument tracking. Eur Radiol
2002; 12:1331-1337.

118. Zennaro H, Dousset V, Viaud B, Allard M, Dehais J, Senegas J, Caille JM. Periganglionic foraminal steroid injections performed under CT control. Am J Neuroradiol 1998; 19:349-352.

119. Groenemeyer DH, Gevargez A, Schindler O, Schirp S, Braun M. CT-guided periradicular injections of corticosteroids in the management of lumbar radiculopathy associated with disk herniation. / Radio 2002; 1-12.

120. Buttermann GR. Lumbar disc herniation regression after successful epidural steroid injection. J Spin Dis Tech 2002; 15: 469-476

121. Buttermann GR. The effect of spinal steroid injections for degenerative disc disease. Spine J 2004; 4:495-505.

122. Buttermann GR. Treatment of lumbar disc herniation: epidural steroid injection compared with discectomy. A prospective, randomized study. J Bone Joint Surg Am 2004; 86-A:670-679.

123. Cyteval C, Thomas E, Decoux E, Sarrabere MP, Cottin A, Blotman F, Taourel P. Cervical radiculopathy: Open study on percutaneous periradicular foraminal steroid infiltration performed under $\mathrm{CT}$ control in 30 patients. AJNR Am J Neuroradiol 2004; 25 : 441-445.

124. Tong HC, Williams JC, Haig AJ, Geisser ME, Chiodo A. Predicting outcomes of transforaminal epidural injections for sciatica. Spine J 2003; 3:430-434.

125. Ng LC, Sell P. Outcomes of a prospective cohort study on peri-radicular infiltration for radicular pain in patients with lumbar disc herniation and spinal stenosis. Eur Spine J 2004; 13:325-329.

126. Botwin KP, Gruber RD, Bouchlas CG, Torres-Ramos FM, Sanelli JT, Freeman ED, Slaten WK, Rao S. Fluoroscopically guided lumbar transformational epidural steroid injections in degenerative lumbar stenosis: an outcome study. Am J Phys Med Rehabil 2002; 81:898-905.

127. Barré L, Lutz GE, Southern D, and Cooper G. Fluoroscopically Guided Caudal Epidural Steroid Injections for Lumbar Spinal Stenosis: A Restrospective Evaluation of Long Term Efficacy. Pain Physician 2004; 7:187-193.

128. Slipman CW, Lipetz JS, DePalma MJ, Jackson HB. Therapeutic selective nerve root block in the nonsurgical treatment of traumatically induced cervical spondylotic radicular pain. Am J Phys Med Rehabil 2004; 83:446-454

129. Slipman C, Lipetz J, Jackson H, Plastaras C, Vresilovic E. Outcomes of Therapeutic Selective Nerve Root Blocks for Whiplash Induced Cervical Radicular Pain. Pain Physician 2001; 4:167-174.

130. Lutze M, Stendel R, Vesper J, Brock M. Periradicular therapy in lumbar radicular syndromes: Methodology and results. Acta Neurochir 1997; 139:719-724.

131. Uhlenbrock D, Arlinghaus J. Results of CT- guided periradicular pain therapy. Rofo Fortschr Geb Rontgenstr Neuen Bildgeb Verfahr 1997; 166:528-534.

132. Le Chevallier PL, Videgrain M, Roulleau P, Delvert JC, Valat JP, Castaing J. Injection of the sacrolumbar roots: A complementary method of staging sciatica. 18 cases. Rev Rhum Mal Osteoartic 1978; 45:473-477.

133. Devulder J. Transforaminal nerve root sleeve injection with corticosteroids, hyaluronidase, and local anesthetic in the failed back surgery syndrome. I Spinal Disord 1998; 11:151-154.

134. Weiner BK, Fraser RD. Foraminal injection for lateral lumbar disc herniation. J Bone Joint Surg 1997; 79-B:804-807.

135. Narozny M, Zanetti M, Boos N. Therapeutic efficacy of selective nerve root blocks in the treatment of lumbar radicular leg pain. Swiss Med Wkly 2001; 131:75-80.

136. Friedman R, Li V, Mehrotra D, Mosuro Y, Atkinson $\mathrm{G}$. Foraminal injection of a painful sacral nerve root using an epidural catheter: Case report. Reg Anesth Pain Med 2002; 27:214-216.

137. Rosenberg SK, Grabinsky A, Kooser C, Boswell M. Effectiveness of transforaminal epidural steroid injections in low back pain: A one year experience. Pain Physician 2002; 5:266-270.

138. Wang JC, Lin E, Brodke DS, Youssef JA. Epidural injections for the treatment of symptomatic lumbar herniated discs. I Spinal Disord Tech 2002; 15:269-272.

139. Botwin KP, Sakalkale DP. Epidural steroid injections in the treatment of symptomatic lumbar spinal stenosis associated with epidural lipomatosis. Am J Phys Med Rehabil 2004; 83:926-930.

140. Schmid G, Vetter S, Gottmann D, Strecker EP. CT-guided epidural/perineural injections in painful disorders of the lumbar spine: Short- and extended-term results. Cardiovasc Intervent Radiol 1999; 22:493498.

141. Groenmeyer DH, Seibel R, Schindler O, Schattauer K, Lange S, Schmidt A. Microinvasive $\mathrm{CT}$ guided periradicular therapy for treatment of chronical functional disorders of the spine. Weiner Medizinische Wochenschrift 1995; 145:129-139.

142. Breivik H, Hesla PE, Molnar I, Lind B. Treatment of chronic low back pain and sciatica. Comparison of caudal epidural injections of bupivacaine and methylprednisolone with bupivacaine followed by saline. In Bonica JJ, AlbeFesard D (eds). Advances in pain research and therapy. Vol. 1., Raven Press, New York, 1976, pp 927932.

143. Bush K, Hillier S. A controlled study of caudal epidural injections of triamcinolone plus procaine for the management of intractable sciatica. Spine 1991; 16:572575.

144. Mathews JA, Mills SB, Jenkins VM, Grimes SM, Morkel MJ, Mathews W, Scott CM, Sittampalam Y. Back pain and sciatica: Controlled trials of manipulation, traction, 
sclerosant and epidural injections. Brit Rheumatol 1987; 26:416-423.

145. Beliveau P. A comparison between epidural anesthesia with and without corticosteroids in the treatment of sciatica. Rheum Phys Med 1971; 11:40-43.

146. Czarski Z. Leczenie rwy kulszowej wstrzykiwaniem hydrokortyzonu inowokainy do rozworu kryzowego. Przeglad Kekarski 1965; 21:511-513.

147. Helsa PE, Breivik H. Epidural analgesia and epidural steroid injection for treatment of chronic low back pain and sciatica. Tidsskr Nor Laegeforen 1979; 99:936939.

148. Revel M, Auleley GR, Alaoui S, Nguyen M, Duruoz T, Eck-Michaud S, Roux C, Amor B. Forceful epidural injections for the treatment of lumbosciatic pain with post-operative lumbar spinal fibrosis. Rev Rhum Engl Ed 1996; 63:270-277.

149. Meadeb J, Rozenberg S, Duquesnoy B, Kuntz JL, Le Loet X, Sebert JL, Le Goff P, Fallut M, Marty M, Blevin S, Guggenbuhl P, Chales G, Duvauferrier R. Forceful sacrococcygeal injections in the treatment of postdiscectomy sciatica. A controlled study versus glucocorticoid injections. Joint Bone Spine 2001; 68:43-49.

150. Manchikanti L, Pampati V, Rivera JJ, Beyer CD, Damron KS, Barnhill RC. Caudal epidural injections with Sarapin steroids in chronic low back pain. Pain Physician 2001; 4:322-335.

151. Manchikanti L., Singh V, Rivera JJ, Pampati V, Beyer CD, Damron KS, Barnhill RC. Ef fectiveness of caudal epidural injections in discogram positive and negative chronic low back pain. Pain Physician 2002; 5 : 18-29.

152. Yates DW. A comparison of the types of epidural injection commonly used in the treatment of low back pain and sciatica. Rheum Rehab 1978; 17:181-186.

153. Waldman SD. The caudal epidural administration of steroids in combination with local anesthetics in the palliation of pain secondary to radiographically documented lumbar herniated disc: A prospective outcome study with 6-months follow-up. Pain Clinic 1998; 11:43-49.

154. Hauswirth R, Michot F. Caudal epidural injection in the treatment of low back pain. Ischweizerische Medizinische Wochenschrift 1982; 112:222-225.

155. Goebert HW Jr, Jallo SJ, Gardner WJ, Wasmuth CE.. Painful radiculopathy treated with epidural injections of procaine and hydrocortisone acetate: Results in $113 \mathrm{pa}$ tients. Anesth Analg 1961; 140:130-134.

156. Ciocon JO, Galindo-Ciocon D, Amaranath L, Galindo D. Caudal epidural blocks for elderly patients with lumbar canal stenosis. J Am Geriatr Soc 1994; 42:593-596.

157. Waldman SD. Complications of cervical epidural nerve blocks with steroids: A prospective study of 790 consecutive blocks. Reg Anesth 1989; 14:149-151.

158. Furman MB, Giovanniello MT, O’Brien EM.
Incidence of intravascular penetration in transforaminal cervical epidural steroid injections. Spine 2003; 28:21-25.

159. Furman MB, O’Brien EM, Zgleszewski TM. Incidence of intravascular penetration in transforaminal lumbosacral epidural steroid injections. Spine 2000; 25:26282632.

160. Botwin KP, Gruber RD, Bouchlas CG, Torres-Ramos FM, Freeman TL, Slaten WK. Complications of fluoroscopically guided transforaminal lumbar epidural injections. Arch Phys Med Rehabil 2000; 81: 1045-1050.

161. Botwin KP, Castellanos R, Rao S, Hanna AF, Torres-Ramos FM, Gruber RD, Bouchlas CG, Fuoco GS. Complications of fluoroscopically guided interlaminar cervical epidural injections. Arch Phys Med Rehabil 2003; 84:627-633.

162. Huang RC, Shapiro GS, Lim M, Sandhu HS, Lutz GE, Herzog RJ. Cervical epidural abscess after epidural steroid injection. Spine 2004; 29:E7-E9.

163. Hooten WM, Kinney MO, Huntoon MA. Epidural abscess and meningitis after epidural corticosteroid injection. Mayo Clin Proc 2004; 79:682-686.

164. Stitz MY, Sommer HM. Accuracy of blind versus fluoroscopically guided caudal epidural injection. Spine 1999; 24:13711376.

165. Williams KN, Jackowski A, Evans PJ. Epidural hematoma requiring surgical decompression following repeated cervical epidural steroid injections for chronic pain. Pain 1990; 42:197-199.

166. Reitman CA, Watters W. Subdural hematoma after cervical epidural steroid injection. Spine 2002; 27:E174-E176.

167. Bromage RP, Benumof JL. Paraplegia following intracord injection during attempted epidural anesthesia under general anesthesia. Reg Anesth Pain Med 1998; 23: 104-107.

168. MacLean CA, Bachman DT. Documented arterial gas embolism after spinal epidural injection. Ann Emerg Med 2001; 38:592595.

169. Yue WM, Tan SB. Distant skip level discitis and vertebral osteomyelitis after caudal epidural injection: A case report of a rare complication of epidural injections. Spine 2003; 28:E209-E211.

170. McMillan MR, Crumpton C. Cortical blindness and neurologic injury complicating cervical transforaminal injection for cervical radiculopathy. Anesthesiology 2003; 99:509-511.

171. Hodges SD, Castleberg RL, Miller T, Ward $R$, Thornburg C. Cervical epidural steroid injection with intrinsic spinal cord damage. Two case reports. Spine 1998; 23: 2137-2142.

172. Mateo E, Lopez-Alarcon MD, Moliner S, Calabuig E, Vivo M, De Andres J, Grau F. Epidural and subarachnoid pneumocephalus after epidural technique. Eur J Anesthesiol 1999; 16:413-417.
173. Katz JA, Lukin R, Bridenbaugh PO, Gunzenhauser L. Subdural intracranial air: An unusual cause of headache after epidural steroid injection. Anesthesiology 1991; 74: 615-618.

174. Benzon HT, Wong HY, Siddiqui T, Ondra S Caution in performing epidural injections in patients on several antiplatelet drugs. Anesthesiology 1999; 91:1558-1559.

175 Waldman SD. Cervical epidural abscess after cervical epidural nerve block with steroids (Letter). Anesth Anal 1991; 72:717.

176. Mamourian AC, Dickman CA, Drayer BP, Sonntag VK. Spinal epidural abscess: Three cases following spinal epidural injection demonstrated with magnetic resonance imaging. Anesthesiology 1993; 78: 204-207.

177. Knight JW, Cordingley JJ, Palazzo MG. Epidural abscess following epidural steroid and local anesthetic injection. Anaesthesia 1997; 52:576-578.

178. Kaul S, Meena AK, Sundaram C, Reddy JM, Naik RT, Murthy JM. Spinal extradural abscess following local steroid injection. Neurol India 2000; 48:181-183.

179. Tekkok IH, Carter DA, Brinker R. Spinal subdural hematoma as a complication of immediate epidural blood patch. Can J Anaesth 1996; 43:306-309.

180. Sabel M, Felsberg J, Neuen-Jacob E, Lichota A, Schnitzler A, Herdmann J. Enlargement of a chronic aseptic lumbar epidural abscess by intraspinal injections - a rare cause of progressive paraparesis. Zentralbl Neurochir 2000; 61:111-114.

181. Gutknecht DR. Chemical meningitis following epidural injections of corticosteroids (Letter). Am J Med 1987; 82:570.

182. Kusher FH, Olson JC. Retinal hemorrhage as a consequence of epidural steroid injection. Arch Opthalmol 1995; 113:309313.

183. Tiso RL, Cutler T, Catania JA, Whalen K. Adverse central nervous system sequelae after selective transforaminal block: the role of corticosteroids. Spine / 2004; 4:468474.

184. Huntoon MA, Martin DP. Paralysis after transforaminal epidural injection and previous spinal surgery. Reg Anesth Pain Med 2004; 29:494-495.

185. Uribe J, Moza K, Jimenez O, Green B, Levi AD. Delayed postoperative spinal epidural hematomas. Spine J 2003; 3:125-129.

186. Nelson DA, Landau WM. Intraspinal steroids: History, efficacy, accidentality, and controversy with review of United States Food and Drug Administration reports. J Neurol Neurosurg Psychiatry 2001; 70: 433-443.

187. Houten JK, Errico TJ. Paraplegia after lumbosacral nerve root block: Report of three cases. The Spine Journal 2002; 2:70-75.

188. Elias M. A rare cause of radiculopathy following transforaminal epidural steroid injection. Pain Clinic 1998; 11:159-160.

189. Brouwers PJ, Kottink EJ, Simon MA, Prevo 
RL. A cervical anterior spinal artery syndrome after diagnostic blockade of the right C6-nerve root. Pain 2001; 91:397399.

190. Nash TP. Comment on A cervical anterior spinal artery syndrome after diagnostic blockade of the right C6-nerve root. Pain 2002; 91:217-218.

191. Stohr M, Mayer K. Nerve-root damage from local injections. Dtsch Med Wochenschr 1976; 101:1218-1220.

192. Milhaud D, Heroum C, Charif M, Saulnier P, Pages M, Blard JM. Dural puncture and corticotherapy as risks factors for cerebral venous sinus thrombosis. Eur J Neruol 2000; 7:123-124.

193. Schultz D. Risk of transforaminal epidural injections. Pain Physician 2004; 7:289290.

194. Helm S, Jasper J, Racz G. Complications of transforaminal epidural injections. Pain Physician 2003; 6:389-390.

195. Young WF. Transient blindness after lumbar epidural steroid injection. Spine 2002; 27:E476-E477.

196. Baker R, Dreyfuss P, Mercer S, Bogduk N. Cervical transforaminal injection or corticosteroids into a radicular artery: A possible mechanism for spinal cord injury. Pain 2003; 109:211-215.

197. Rozin L, Rozin R, Koehler SA, Shakir A, Ladham S, Barmada M, Dominick J, Wecht CH. Death during transforaminal epidural steroid nerve root block $\left(C_{7}\right)$ due to perforation of the left vertebral artery. Am J Forensic Med Pathol 2003; 24:351-355.

198. Nishimura H, Uemura Y, Fukuda S, Kamada Y, Moriwaki T. Two cases of pyogenic cervical discitis presenting tetraparesis. No Shinkei Geka 2000; 28:631-637.

199. McHaourab AS. Cervical epidural ste- roid injection: impact of cervical epidural anatomy. Anesthesiology 2004; 101:12381239.

200. Ward A, Watson J, Wood P, Dunne C, Kerr D. Glucocorticoid epidural for sciatica: Metabolic and endocrine sequelae. Rheumatology 2002; 41:68-71.

201. Manchikanti L, Pampati V, Beyer CD, Damron KS, Cash KA, Moss TL. The effect of neuraxial steroids on weight and bone mass density: A prospective evaluation. Pain Physician 2000; 3:357-366.

202. Sullivan WJ, Willick SE, Chira-Adisai W, Zuhosky J, Tyburski M, Dreyfuss P, Prather $\mathrm{H}$, Press JM. Incidence of intravascular uptake in lumbar spinal injection procedures. Spine 2000; 25:481-486.

203. Manchikanti L, Cash KA, Pampati V, Damron KS, McManus CD.. Evaluation of lumbar transforaminal epidural injections with needle placement and contrast flow patterns: A prospective, descriptive report. Pain Physician 2004; 7:217-224.

204. Huntoon MA. The ascending and deep cervical arteries are vulnerable to injury during cervical transforaminal epidural injections: An anatomic study. Presented at the ASA Annual Meeting, October 23-27, 2004, Las Vegas, Nevada.

205. Cousins MJ. An additional dimension to the efficacy of epidural steroids. Anesthesiology 2000; 93:565.

206. Manchikanti L. Role of neuraxial steroids in interventional pain management. Pain Physician 2002; 5:182-199.

207. Delaney TJ, Rowlingson JC, Carron H, Butler A. Epidural steroid effects on nerves and meninges. Anesth Analg 1980; 58: 610-614.

208. MacKinnon Se, Hudson AR, Gentilli R. Peripheral nerve injection injury with steroid agents. Plast Reconstr Surg 1982; 69:482489.

209. Chino N, Awad EA, Kottke FJ. Pathology of propylene glycol administered by perineural and intramuscular injection in rats. Arch Phys Med Rehab 1974; 55:33-38.

210. Benzon HT, Gissen AJ, Strichartz GR, Avram MJ, Covino BG. The effect of polyethylene glycol on mammalian nerve impulses. Anesth Analg 1987; 66:553-559.

211. Abram SE, Marsala M, Yaksh TL. Analgesic and neurotoxic effects of intrathecal corticosteroids in rats. Anesthesiology 1994; 81:1198-1205.

212. Latham JM, Fraser RD, Moore RJ, Blumbergs PC, Bogduk N. The pathologic effects of intrathecal betamethasone. Spine 1997; 22:1558-1562.

213. Robustelli della Cuna FS, Mella M, Magistrali G, Ricci M, Losurdo A, Goglio AM. Stability and compatibility of methylprednisolone acetate and ropivacaine hydrochloride in polypropylene syringes for epidural administration. Am J Health Syst Pharm 2001; 58:1753-1756.

214. Swai EA, Rosen M. An attempt to develop a model to study the effects of intrathecal steroids. Eur J Anaesthesiol 1986; 3:127136.

215. Dunbar SA, Manikantan P, Philip J. Epidural infusion pressure in degenerative spinal disease before and after epidural steroid therapy. Anesth Analg 2002; 94:417-420.

216. Slucky AV, Sacks MS, Pallares VS, Malinin TI, Eismont FJ. Effects of epidural steroids on lumbar dura material properties. J Spin Disord 1999; 12:331-340.

217. Pounder D, Elliott S. An awake patient may not detect spinal cord puncture. Anaesthesia 2000; 55:194. 
